\title{
Changes in the trajectory of Long Covid symptoms following COVID-19 vaccination: community-based cohort study
}

Daniel Ayoubkhani, ${ }^{1,2}$ Principal Statistician

Charlotte Bermingham, ${ }^{1}$ Senior Statistician

Koen B. Pouwels, ${ }^{3,4}$ Senior Researcher

Myer Glickman, ${ }^{1}$ Head of Epidemiology, Climate and Global Health

Vahé Nafilyan, ${ }^{1,5}$ Lead Statistician

Francesco Zaccardi, ${ }^{2}$ Clinical Epidemiologist

Kamlesh Khunti, ${ }^{2}$ Professor of Primary Care Diabetes and Vascular Medicine

Nisreen A. Alwan, ${ }^{6,7,8}$ Associate Professor in Public Health

A. Sarah Walker, ${ }^{3,9}$ Professor of Medical Statistics and Epidemiology

\footnotetext{
${ }^{1}$ Health Analysis and Life Events Division, Office for National Statistics, Newport, UK

${ }^{2}$ Leicester Real World Evidence Unit, Diabetes Research Centre, University of Leicester, Leicester, UK

${ }^{3}$ National Institute for Health Research Health Protection Research Unit in Healthcare Associated Infections and Antimicrobial Resistance, University of Oxford, Oxford, UK

${ }^{4}$ Health Economics Research Centre, Nuffield Department of Population Health, University of Oxford, Oxford, UK

${ }^{5}$ Faculty of Public Health, Environment and Society, London School of Hygiene \& Tropical Medicine, London, UK

${ }^{6}$ School of Primary Care, Population Sciences and Medical Education, Faculty of Medicine, University of Southampton, Southampton, UK

${ }^{7}$ NIHR Southampton Biomedical Research Centre, University of Southampton and University Hospital Southampton NHS Foundation Trust, Southampton, UK

8 NIHR Applied Research Collaboration (ARC) Wessex, Southampton, UK

${ }^{9}$ Nuffield Department of Medicine, University of Oxford, Oxford, UK
}

Corresponding author: Daniel Ayoubkhani, daniel.ayoubkhani@ons.gov.uk

Word count: 3,691

Abstract word count: 258 
medRxiv preprint doi: https://doi.org/10.1101/2021.12.09.21267516; this version posted December 9, 2021. The copyright holder for this preprint (which was not certified by peer review) is the author/funder, who has granted medRxiv a license to display the preprint in

perpetuity.
It is made available under a CC-BY 4.0 International license.

\begin{abstract}
Objective: To estimate associations between COVID-19 vaccination and Long Covid symptoms in adults who were infected with SARS-CoV-2 prior to vaccination.
\end{abstract}

Design: Observational cohort study using individual-level interrupted time series analysis.

Setting: Random sample from the community population of the UK.

Participants: 28,356 COVID-19 Infection Survey participants (mean age 46 years, 56\% female, $89 \%$ white) aged 18 to 69 years who received at least their first vaccination after test-confirmed infection.

Main outcome measures: Presence of long Covid symptoms at least 12 weeks after infection over the follow-up period 3 February to 5 September 2021.

Results: Median follow-up was 141 days from first vaccination (among all participants) and 67 days from second vaccination ( $84 \%$ of participants). First vaccination was associated with an initial $12.8 \%$ decrease (95\% confidence interval: $-18.6 \%$ to $-6.6 \%$ ) in the odds of Long Covid, but increasing by $0.3 \%(-0.6 \%$ to $+1.2 \%)$ per week after the first dose. Second vaccination was associated with an $8.8 \%$ decrease $(-14.1 \%$ to $-3.1 \%)$ in the odds of Long Covid, with the odds subsequently decreasing by $0.8 \%(-1.2 \%$ to $-0.4 \%)$ per week. There was no statistical evidence of heterogeneity in associations between vaccination and Long Covid by socio-demographic characteristics, health status, whether hospitalised with acute COVID-19, vaccine type (adenovirus vector or mRNA), or duration from infection to vaccination.

Conclusions: The likelihood of Long Covid symptoms reduced after COVID-19 vaccination, and the improvement was sustained over the follow-up period after the second dose. Vaccination may contribute to a reduction in the population health burden of Long Covid, though longer follow-up time is needed. 
medRxiv preprint doi: https://doi.org/10.1101/2021.12.09.21267516; this version posted December 9, 2021. The copyright holder for this preprint (which was not certified by peer review) is the author/funder, who has granted medRxiv a license to display the preprint in perpetuity.

It is made available under a CC-BY 4.0 International license.

\section{Summary box}

\section{What is already known on this topic}

- COVID-19 vaccines are effective at reducing rates of SARS-CoV-2 infection, transmission, hospitalisation, and death

- The incidence of Long Covid may be reduced if infected after vaccination, but the relationship between vaccination and pre-existing long COVID symptoms is unclear, as published studies are generally small and with self-selected participants

\section{What this study adds}

- The likelihood of Long Covid symptoms reduced after COVID-19 vaccination, and the improvement was sustained over the follow-up period after the second dose

- There was no evidence of differences in this relationship by socio-demographic characteristics, health-related factors, vaccine type, or duration from infection to vaccination

- Although causality cannot be inferred from this observational evidence, vaccination may contribute to a reduction in the population health burden of Long Covid; further research is needed to understand the biological mechanisms that may ultimately contribute to the development of therapeutics for Long Covid 
medRxiv preprint doi: https://doi.org/10.1101/2021.12.09.21267516; this version posted December $9,2021$. The copyright holder for this preprint (which was not certified by peer review) is the author/funder, who has granted medRxiv a license to display the preprint in perpetuity.

It is made available under a CC-BY 4.0 International license.

\section{Introduction}

Symptoms may persist for months following SARS-CoV-2 infection, defined in UK clinical guidelines [1] as ongoing symptomatic COVID-19 (signs and symptoms from 4 to 12 weeks post-onset) or post-COVID-19 syndrome (more than 12 weeks post-onset). These symptoms are collectively and commonly referred to as Long Covid. Long Covid is characterised by a range of symptoms across organ systems, including fatigue, shortness of breath, and cognitive impairment [2], often with undulating periods of wellness followed by relapse [3-5]. By February 2021, nearly 6\% of adults in England may have experienced prolonged symptoms following coronavirus infection since the pandemic began [6], and 1.2 million people in private households in the UK (1.9\%) were estimated to be reporting Long Covid symptoms in October 2021, with symptoms having a detrimental impact on the day-to-day activities of two-thirds of these individuals [2].

Population-level immunisation against COVID-19 began in the UK on 8 December 2020, and both adenovirus vector and messenger ribonucleic acid (mRNA) vaccines have demonstrated safety and efficacy in trials [7-10] and real-world effectiveness at reducing rates of infection [11-12], transmission [13], hospitalisation [14] and death [14-15]. However, the impact of vaccination on Long Covid symptoms is uncertain. Preliminary research suggests that persistent symptoms are less common in breakthrough infections [16], but studies of people with pre-existing Long Covid have been small and with self-selected study participants [17-19].

We therefore used data from the Office for National Statistics (ONS) COVID-19 Infection Survey (CIS), a large, community-based population survey of randomly sampled UK households, to assess changes in the trajectory of Long Covid symptoms in adults infected with SARS-CoV-2 prior to receiving their first vaccination, and heterogeneity in trajectories by socio-demographics, health-related factors, vaccine type, and duration since infection.

\section{Methods}

\section{Study data}

Data were obtained from the CIS (ISRCTN21086382, www.ndm.ox.ac.uk/covid-19/covid-19infection-survey/protocol-and-information-sheets) [20], a longitudinal survey of individuals aged 2 years or over in randomly sampled UK households (excluding communal establishments such as hospitals, care homes, halls of residence, and prisons), with ethical approval from the South Central Berkshire B Research Ethics Committee (20/SC/0195). After verbal agreement to participate, each selected household was visited by a study worker to provide written confirmed consent (from parents/carers for those aged 2 to 15 years; those aged 10 to 15 years also provided written assent). At the first visit, participants could consent for (optional) follow-up visits every week for the next month and then monthly for 12 months or longer. Supplementary Table 1 shows survey response rates.

All participants provided a nose and throat self-swab for polymerase chain reaction (PCR) testing at every follow-up visit. Individuals aged 16 years or older in a random subsample of households (initially 10\% but expanded from April 2021), and those in households where another household member previously tested positive for SARS-CoV-2, were invited to provide monthly blood samples for S-antibody testing. Participants also reported whether they had tested positive for the virus or antibodies outside of the study (for example, through national testing programmes). 
medRxiv preprint doi: https://doi.org/10.1101/2021.12.09.21267516; this version posted December $9,2021$. The copyright holder for this preprint (which was not certified by peer review) is the author/funder, who has granted medRxiv a license to display the preprint in perpetuity.

It is made available under a CC-BY 4.0 International license .

At every monthly visit since 3 February 2021, all CIS participants were asked whether they would describe themselves as currently experiencing Long Covid, defined as symptoms persisting for at least four weeks from confirmed or suspected coronavirus infection that could not be explained by another health condition. This definition uses self-classification of Long Covid, rather than a pre-specified symptoms list or clinical diagnosis, and thus reflects participants' perception of whether their lived experience is consistent with what they understand of the condition. Participants who responded positively to the Long Covid question were further asked about the extent to which their day-to-day activities were limited as a result, and the presence of 21 individual symptoms as part of their experience of Long Covid (selected on the basis of being among the most commonly reported when the survey question was developed [4, 5, 21]; see Supplementary Table 2 for the full list).

For participants in England, vaccination information (number of doses, dates, manufacturer) was obtained from self-reported CIS responses and linked National Immunisation Management System (NIMS) records, with NIMS being prioritised where data conflicted. Concordance between self-reported and NIMS data was previously found to be high regarding vaccination type (98\%) and date (95\% within \pm 7 days) [11]. Administrative records were not available for participants in Wales, Scotland, and Northern Ireland, so vaccination data for these individuals were taken from the CIS alone.

\section{Study design}

The analysis included CIS participants aged 18 to 69 years on 3 February 2021. Participants were included if they: responded to the survey question on Long Covid at least once up to 5 September 2021 (end of follow-up); received at least one COVID-19 vaccination before or during the follow-up period; and received a positive swab or blood test for SARS-CoV-2, either through the CIS or reported outside of the study, prior to vaccination. We excluded CIS participants remaining unvaccinated by 5 September 2021 because they were likely to differ from those who were vaccinated according to unmeasured characteristics (for example, personal considerations related to vaccine hesitancy).

\section{Infection date}

Time of infection was the date of first positive swab or antibody test (ignoring blood tests after first vaccination), or the date when the participant first thought they had COVID-19 that was later confirmed by a positive test, whichever was earlier. Although the CIS question asks about Long Covid symptoms persisting for at least four weeks from infection, for this analysis we used a longer 12-week threshold, consistent with the UK clinical case definition of post-COVID-19 syndrome [1] and the World Health Organisation's definition of post COVID-19 condition [22]. We therefore excluded any follow-up visits within 12 weeks of infection date.

\section{Exposures}

The exposures of interest were first and second vaccinations of an adenovirus vector (Oxford/AstraZeneca, ChAdOx1 nCoV-19 [AZD1222]) or mRNA (Pfizer/BioNTech, BNT162b2; Moderna, mRNA-1273) COVID-19 vaccine. For each vaccine dose, we estimated the associated change in outcomes using a binary variable to indicate whether participants had received each dose at each follow-up visit; and a variable equal to the number of days since receiving each dose at each follow-up visit to estimate postvaccination changes in the outcome trajectory (set to 0 for visits before receiving each dose). This specification implies that any change in the odds of Long Covid occurs instantly following vaccination, but in reality, this may take place over several days or weeks. 
medRxiv preprint doi: https://doi.org/10.1101/2021.12.09.21267516; this version posted December $9,2021$. The copyright holder for this preprint (which was not certified by peer review) is the author/funder, who has granted medRxiv a license to display the preprint in perpetuity.

It is made available under a CC-BY 4.0 International license.

\section{Outcomes}

The primary outcome at each visit was Long Covid of any severity. Secondary outcomes comprised Long Covid resulting in activity limitation (day-to-day activities limited "a little" or "a lot" versus "not at all" or no Long Covid); the 10 individual symptoms that were most commonly reported over the follow-up period; and whether the participant was experiencing more than three or five of the 21 symptoms included on the survey.

\section{Covariates}

As well as time from infection and the exposure variables detailed above to modify the time trajectory of Long Covid, we adjusted for covariates hypothesised to be related to vaccine type and timing [23] and the probability of experiencing Long Covid symptoms [2]: age; sex; white or non-white ethnicity; region/country; area deprivation quintile group; health status; whether a patient-facing health or social care worker; whether hospitalised with acute COVID-19; and calendar time of infection. Specifications of these covariates can be found in Supplementary Table 3.

\section{Statistical analysis}

We compared covariates between participants receiving adenovirus vector and mRNA vaccines using means and proportions for continuous and categorical variables, respectively. Standardized differences $>10 \%$ indicated large differences [24].

Associations between exposures and outcomes were estimated using an individual-level interrupted time series approach. For each outcome, we included all exposures and covariates in a binary logistic regression model and estimated robust (clustered) standard errors to account for intra-participant correlation due to having repeated measures. We explored various specifications for modelling time since infection, finding that a linear time trend minimised the Bayesian Information Criterion for the primary outcome.

We explored heterogeneity in associations between vaccination and Long Covid by interacting all four exposure variables (change in level and slope after each dose) with each of: age group ( 18 to $<30$ years, 30 to $<40$ years, 40 to $<50$ years, 50 years to $<60$ years, $\geq 60$ years); sex; white or non-white ethnicity; area deprivation quintile group; health status; hospitalisation with acute COVID-19; vaccine type (adenovirus vector or mRNA); and duration from infection to first vaccination (modelled as a restricted cubic spline). For each outcome, statistically significant interactions were identified at the $5 \%$ level after performing Holm-Bonferroni and Benjamini-Yekutieli corrections to $p$-values to account for multiple comparisons across exposures and modifiers. All statistical analyses were performed using $\mathrm{R}$ version 3.6.

\section{Sensitivity analyses}

We restricted the sample firstly to participants with at least one observation before and after each vaccination, and secondly to those with at least three observations after each vaccination. We omitted follow-up visits within the first week after each vaccination, which may have been influenced by post-vaccine side effects. We added CIS participants who remained unvaccinated by their last follow-up visit during the study period (who were excluded from the main analysis). We excluded participants infected before the start of the second wave on 11 September 2020 [25], as mass testing for SARS-CoV-2 was largely unavailable in the first wave and so these infections were likely to have been more severe than the majority included in the analysis. Finally, we reset the infection date for $2.5 \%$ of participants where this was determined by when the participant first thought they had 
medRxiv preprint doi: https://doi.org/10.1101/2021.12.09.21267516; this version posted December $9,2021$. The copyright holder for this preprint (which was not certified by peer review) is the author/funder, who has granted medRxiv a license to display the preprint in perpetuity.

It is made available under a CC-BY 4.0 International license .

COVID-19 (later confirmed by a positive test) that was $>14$ days before a positive swab (the estimated maximum incubation period [26]). These participants may have been reinfected, but only their second infection was validated by means of a positive test, so the infection date was moved forward to the date of this test.

\section{Patient and public involvement}

NAA has lived experience of Long Covid. Although we did not directly involve patients and the public more broadly, the study design was informed by views expressed by patient representatives in monthly meetings attended by DA (the Department of Health and Social Care's Long Covid ministerial roundtable, NHS England's Long Covid national taskforce).

\section{Results}

\section{Description of the study sample}

Of $323,685 \mathrm{CIS}$ participants aged 18 to 69 years with at least one visit between 3 February and 5 September 2021, 28,356 had test-confirmed SARS-CoV-2 at least 12 weeks before their final visit and had been vaccinated post-infection, and were therefore included in analysis (Supplementary Figure 1).

Median time to the final follow-up visit was 169 (interquartile range [IQR]: 141 to 185) days from first visit, and 267 (219 to 431) days from first infection. By design, all study participants received their first vaccination by 5 September 2021, 12,971 (45.7\%) after 3 February; 23,753 (83.8\%) participants were double vaccinated by 5 September 2021, 20,335 (71.7\%) receiving their second dose after 3 February. Supplementary Table 4 shows vaccination status during follow-up by age and health status (two of the main vaccination prioritisation determinants). Participants had a median of 4 (IQR: 2 to 5) visits after their first dose and, among those double-vaccinated, 2 ( 1 to 3 ) visits after their second dose.

At last visit, the mean age of participants was 46 years (standard deviation [SD] 14 years), $55.6 \%$ were female, and $88.7 \%$ were white (Table 1). Compared with participants receiving an adenovirus vector vaccine, those mRNA vaccinated were on average younger (mean 40 versus 51 years), and more likely to be of non-white ethnicity (13.7\% versus $9.4 \%$ ), resident in London (27.0\% versus $22.4 \%$ ) or Northern Ireland (3.3\% versus $1.5 \%)$, and a patientfacing health or social care worker (17.1\% versus $6.4 \%)$.

\section{Long Covid trajectories before and after vaccination}

Long Covid symptoms of any severity were reported by 6,729 participants (23.7\%) at least once during follow-up. Before vaccination, the odds of experiencing Long Covid decreased by $0.3 \%(-0.9 \%$ to $+0.2 \%)$ per week from infection (Table 2$)$. First vaccination was associated with an initial $12.8 \%$ decrease (95\% Cl: $-18.6 \%$ to $-6.6 \%)$ in the odds, followed by an increase of $0.3 \%(-0.6 \%$ to $+1.2 \%)$ per week until receiving the second dose. Second vaccination was associated with an initial $8.8 \%$ decrease $(-14.1 \%$ to $-3.1 \%)$ in the odds, followed by a decrease of $0.8 \%(-1.2 \%$ to $-0.4 \%)$ per week.

Long Covid resulting in activity limitation was reported by 4,747 participants (16.7\%) at least once during follow-up. First vaccination was associated with an initial $12.3 \%$ decrease ($19.5 \%$ to $-4.5 \%$ ) in the odds of activity-limiting Long Covid, followed by an increase of $0.9 \%$ $(-0.2 \%$ to $+1.9 \%)$ per week until receiving the second dose. Second vaccination was associated with an initial $9.1 \%$ decrease $(-15.6 \%$ to $-2.1 \%)$ in the odds, followed by a decrease of $0.5 \%(-1.0 \%$ to $+0.05 \%)$ per week. 
medRxiv preprint doi: https://doi.org/10.1101/2021.12.09.21267516; this version posted December $9,2021$. The copyright holder for this preprint (which was not certified by peer review) is the author/funder, who has granted medRxiv a license to display the preprint in perpetuity.

It is made available under a CC-BY 4.0 International license .

To illustrate the impact of each vaccination, Figure 1 shows the estimated probability of reporting Long Covid for a hypothetical participant receiving their first vaccination 24 weeks after infection and their second dose 12 weeks later. Sensitivity analyses (Supplementary Figures 2a-h) were generally consistent with the main results. However, there was stronger evidence of a change to an increasing trend in Long Covid between first and second vaccinations when restricting the sample to participants who received their first dose during the follow-up period 3 February to 5 September 2021 ( $p<0.001$ for Long Covid of any severity, $p=0.007$ for activity-limiting Long Covid).

\section{Heterogeneity by vaccine type, duration since infection, and participant characteristics}

There was no statistical evidence of differences in post-vaccination Long Covid trajectories between participants receiving adenovirus vector and mRNA vaccines (Table 3, Figure 2). Numerically, vaccination was associated with an initial $14.9 \%$ decrease $(-21.8 \%$ to $-7.5 \%)$ in the odds of Long Covid following first adenovirus vector vaccination, and an initial $8.9 \%$ decrease $(-18.2 \%$ to $+1.4 \%)$ following first mRNA vaccination. Decreases in the odds after second vaccination were numerically similar between vaccine types, at $8.7 \%(-15.4 \%$ to $1.4 \%)$ for adenovirus vector and $8.9 \%(-17.6 \%$ to $+0.7 \%)$ for mRNA.

The odds of Long Covid after first vaccination numerically decreased with duration from infection, with estimated decreases of $24.8 \%, 16.5 \%$, and $4.8 \%$ for participants first vaccinated 9, 12, and 15 months after infection (Supplementary Figures 3a-b). However, duration from infection to first vaccination was not a statistically significant moderator of the vaccination-Long Covid relationship (Supplementary Tables 5a to 5d).

There was no statistical evidence of differences in post-vaccination Long Covid trends according to socio-demographic characteristics (age, sex, ethnic group, area deprivation) or health-related factors (self-reported health status not related to COVID-19, whether hospitalised with acute COVID-19) (Supplementary Tables 5a to 5d).

\section{Trajectories of individual symptoms}

The odds of experiencing most symptoms, as well as more than three or five symptoms together, initially numerically decreased after each vaccination (Figure 3). After first vaccination, the largest numerical decreases were observed for loss of smell $(-12.5 \%$, $21.5 \%$ to $-2.5 \%)$, loss of taste $(-9.2 \%,-19.8 \%$ to $+2.7 \%)$, and trouble sleeping $(-8.8 \%$, $19.4 \%$ to $+3.3 \%)$. After second vaccination, the largest numerical decreases were observed for fatigue $(-9.7 \%,-16.5 \%$ to $-2.4 \%)$, headache $(-9.0 \%,-18.1 \%$ to $+1.0 \%)$, and trouble sleeping $(-9.0 \%,-18.2 \%$ to $+1.2 \%)$.

Similar to Long Covid overall, the odds of experiencing most individual symptoms, and more than three or five symptoms together, numerically decreased after the first vaccination. Trends were generally upwards between the first and second vaccinations, with most returning to a declining or flat trend after the second dose. However, lack of statistical power meant that for most symptoms, the data were compatible with both initial increases and decreases, and with both upward and downward trends, in the likelihood of experiencing symptoms after each vaccination (Supplementary Table 6).

\section{Discussion}

In this community-based study of adults aged 18 to 69 years infected with SARS-CoV-2 prior to vaccination, we found that the odds of experiencing Long Covid symptoms that had 
medRxiv preprint doi: https://doi.org/10.1101/2021.12.09.21267516; this version posted December $9,2021$. The copyright holder for this preprint (which was not certified by peer review) is the author/funder, who has granted medRxiv a license to display the preprint in perpetuity.

It is made available under a CC-BY 4.0 International license .

persisted for at least 12 weeks fell by an average of $13 \%$ after receiving a first COVID-19 vaccination. However, it is unclear from the data whether the improvement was sustained until receiving the second vaccination. Receiving a second vaccination was associated with a further $9 \%$ decrease in the odds of Long Covid, and there was statistical evidence of a sustained improvement after this, at least over the median follow-up time of 67 days. Similar findings were obtained when focussing on Long Covid severe enough to result in functional impairment.

We found no statistical evidence of heterogeneity in the associations between vaccination and Long Covid symptoms according to vaccine type, duration from infection to first vaccination, socio-demographic characteristics including age, sex, ethnicity, and area deprivation, self-reported health status, and whether hospitalised with acute COVID-19. However, this observational study was unlikely to have been sufficiently powered to detect these associations, particularly given the multiplicity of testing, and absence of evidence does not necessarily imply evidence of absence.

\section{Findings in context}

Our results substantially add to existing evidence on the epidemiology of Long Covid after vaccination. While previous studies are generally coherent in terms of their findings, ours exploits a considerably larger sample drawn at random from the community population, so the results are likely to be more precise and generalizable.

A study of 44 vaccinated patients and 22 unvaccinated controls previously hospitalised with COVID-19 in the UK, which inevitably had limited power to detect clinically relevant effects, found no evidence of vaccination being associated with worsening of Long Covid symptoms or quality of life [17]. A study of 455 self-selected participants in France found reduced symptom burden and double the rate of remission at 120 days post-vaccination compared with unvaccinated controls [18]. A non-controlled study of 900 social media users found that over half had experienced an improvement in symptoms after vaccination while just $7 \%$ reported a deterioration [19].

COVID-19 vaccination effectively reduces rates of infection [11-12] and transmission [13]. Evidence also suggests that Long Covid incidence is reduced in those infected after vaccination; in a study of 906 mobile phone app users, the odds of having symptoms $\geq 28$ days post-infection was approximately halved in fully vaccinated participants versus unvaccinated controls [16]. Together with our results, these findings suggest that COVID-19 vaccination may reduce the population prevalence of Long Covid by reducing the risk of continuing to experience persistent symptoms in those who already have them when vaccinated; developing persistent symptoms following breakthrough infections; being infected in the first place; and transmitting the virus following infection.

Our principal finding, of a decrease in the likelihood of experiencing Long Covid symptoms after receiving a second vaccination, supports hypothesised biological mechanisms. People with Long Covid experiencing dysregulation of the immune system may benefit from vaccine-induced diversion of autoimmune processes, while any residual viral reservoir may be destroyed by the antibody response [27]. However, whether this is a long-lasting 'reset' of the immune system remains to be established.

The symptom trajectory following the initial fall after first vaccination was unclear, being compatible with both increasing and decreasing odds of Long Covid over time. However, there was evidence of an increasing trend when the sample was restricted to participants 
medRxiv preprint doi: https://doi.org/10.1101/2021.12.09.21267516; this version posted December 9, 2021. The copyright holder for this preprint (which was not certified by peer review) is the author/funder, who has granted medRxiv a license to display the preprint in perpetuity.

It is made available under a CC-BY 4.0 International license.

vaccinated during the follow-up period. Relapsing symptoms are common in Long Covid [35] and persistent symptoms are associated with weak antibody response [28], so it is possible that receiving a first dose alone is insufficient for sustained improvement in some people.

\section{Strengths and limitations}

With 28,356 adults in our sample, this is the largest study to date internationally on Long Covid and COVID-19 vaccination, and the first to investigate post-vaccine symptom trajectories. The main strength of the study is its use of the CIS, a large survey of approximately half a million people from the community population of the UK with longitudinal follow-up. Random sampling from address lists mitigates against selection bias, while the prospective design means that survey responses are not subject to outcome recall bias (such as participants overestimating the duration of previously experienced symptoms). All CIS participants are swabbed for SARS-CoV-2 at every follow-up visit, irrespective of symptoms, so our study includes asymptomatic as well symptomatic infections.

The study also has limitations. Its observational nature means that causality cannot be inferred, and placebo and side effects of vaccination may have contributed to our findings; however, estimates were robust to excluding follow-up visits within the first week of each vaccination, suggesting that the impact of these effects is likely to be small. Although we adjusted for a wide range of potential confounders, unmeasured factors, such as those related to take-up of a second vaccination, may remain.

The observed changes after vaccination could be related to the relapsing-remitting nature of symptoms experienced by many people living with Long Covid [3-5] rather than a causal effect of the vaccine. Future analysis should consider differing patterns of illness, including quantification of the frequency and duration of symptom-free periods after vaccination.

Although all infections were test-confirmed, Long Covid status was self-reported and we did not have data on formal clinical diagnoses, so we cannot exclude some participants' symptoms being caused by a medical condition other than SARS-CoV-2 infection.

It is possible that the average improvement in Long Covid symptoms and functional impact may wane with time, and longer-term follow-up is required to establish whether the estimated changes after second vaccination are sustained. Follow-up after receipt of a booster dose, now widely available in the UK adult population, is also required. The study sample was restricted to participants aged 18 to 69 years, so our findings may not generalize to children or older adults, nor may they apply to people who had not received a vaccine by 5 September 2021, in particular those who are vaccine-hesitant because of their Long Covid symptoms. However, our results were insensitive to whether unvaccinated participants were included in the study sample.

\section{Conclusions}

In summary, we found that COVID-19 vaccination is associated with a decrease in the likelihood of continuing to experience Long Covid symptoms in adults aged 18 to 69 years, and this appeared to be sustained after the second dose. Our results suggest that vaccination of people previously infected may be associated with a reduction in the burden of Long Covid on population health, at least in the first few months following vaccination. Further research is required to evaluate the long-term relationship between vaccination and Long Covid, and understand the biological mechanisms underpinning any improvements in symptoms following vaccination. Such research may contribute to the development of therapeutics for Long Covid. 
medRxiv preprint doi: https://doi.org/10.1101/2021.12.09.21267516; this version posted December $9,2021$. The copyright holder for this preprint (which was not certified by peer review) is the author/funder, who has granted medRxiv a license to display the preprint in perpetuity.

It is made available under a CC-BY 4.0 International license.

\section{Acknowledgements}

KK and FZ are supported by the National Institute for Health Research (NIHR) Applied Research Collaboration East Midlands (ARC EM) and the NIHR Leicester Biomedical Research Centre (BRC). KBP and ASW are supported by the NIHR Health Protection Research Unit in Healthcare Associated Infections and Antimicrobial Resistance (NIHR200915), a partnership between the UK Health Security Agency (UKHSA) and the University of Oxford. KBP is also supported by the Huo Family Foundation. ASW is also supported by the NIHR Oxford Biomedical Research Centre and is an NIHR Senior Investigator. NAA has lived experience of Long Covid and is a co-investigator on the NIHRfunded STIMULATE-ICP study. The views expressed are those of the authors and are not necessarily those of the National Health Service, the NIHR, the Department of Health and Social Care, or the UK Health Security Agency.

\section{Footnotes}

Contributors: DA, KBP, MG, VN, NAA and ASW conceptualised and designed the study. DA and $\mathrm{CB}$ prepared the study data and performed the statistical analysis. All authors contributed to interpretation of the results. DA and CB were responsible for the first draft of the manuscript. All authors contributed to critical revision of the manuscript. All authors approved the final manuscript.

The lead author (the manuscript's guarantor) affirms that the manuscript is an honest, accurate, and transparent account of the study being reported; that no important aspects of the study have been omitted; and that any discrepancies from the study as originally planned (and, if relevant, registered) have been explained.

Funding: The CIS is funded by the Department of Health and Social Care with in-kind support from the Welsh Government, the Department of Health on behalf of the Northern Ireland Government, and the Scottish Government.

Competing interests: All authors have completed the ICMJE uniform disclosure form at http://www.icmje.org/disclosure-of-interest/ and declare: no support from any organisation for the submitted work; no financial relationships with any organisations that might have an interest in the submitted work in the previous three years; KK chairs the Long Covid research-funded group reporting to the Chief Medical Officer, chairs the Ethnicity Subgroup of the UK Scientific Advisory Group for Emergencies (SAGE), and is a Member of SAGE.

Ethical approval: Ethical approval for this study was obtained from the National Statistician's Data Ethics Advisory Committee (NSDEC(20)12). The CIS received ethical approval from the South Central Berkshire B Research Ethics Committee (20/SC/0195).

Data sharing: De-identified study data are available to accredited researchers in the ONS Secure Research Service (SRS) under part 5, chapter 5 of the Digital Economy Act 2017. For further information about accreditation, contact research.support@ons.gov.uk or visit: ons.gov.uk/aboutus/whatwedo/statistics/requestingstatistics/approvedresearcherscheme

Dissemination to participants and related patient and public communities: The use of deidentified data precludes direct dissemination to participants. For the purpose of open access, the authors have applied a Creative Commons Attribution (CC BY) licence to any Author Accepted Manuscript version arising 
medRxiv preprint doi: https://doi.org/10.1101/2021.12.09.21267516; this version posted December 9, 2021. The copyright holder for this preprint (which was not certified by peer review) is the author/funder, who has granted medRxiv a license to display the preprint in

It is made available under a CC-BY 4.0 International license.

\section{References}

[1] National Institute for Health and Care Excellence. COVID-19 rapid guideline: managing the longterm effects of COVID-19. 2021. https://www.nice.org.uk/guidance/ng188

[2] Office for National Statistics. Prevalence of ongoing symptoms following coronavirus (COVID19) infection in the UK: 2 December 2021. 2021.

https://www.ons.gov.uk/peoplepopulationandcommunity/healthandsocialcare/conditionsanddisea ses/bulletins/prevalenceofongoingsymptomsfollowingcoronaviruscovid19infectionintheuk/2dece mber2021

[3] National Institute for Health Research. Living with Covid19 - Second review. 2021. https://evidence.nihr.ac.uk/themedreview/living-with-covid19-second-review

[4] Ziauddeen N, Gurdasani D, O'Hara ME, et al. Characteristics of Long Covid: findings from a social media survey. medRxiv [Preprint] 2021.

https://www.medrxiv.org/content/10.1101/2021.03.21.21253968v2

[5] Davis HE, Assaf GS, McCorkell L, et al. Characterizing long COVID in an international cohort: 7 months of symptoms and their impact. EClinicalMedicine 2021;38:101019. doi:10.1016/j.eclinm.2021.101019

[6] Whitaker M, Elliott J, Chadeau-Hyam M, et al. Persistent symptoms following SARS-CoV-2 infection in a random community sample of 508,707 people. medRxiv [Preprint] 2021. https://www.medrxiv.org/content/10.1101/2021.06.28.21259452v1

[7] Falsey AR, Sobieszczyk ME, Hirsch I, et al. Phase 3 Safety and Efficacy of AZD1222 (ChAdOx1 nCoV-19) Covid-19 Vaccine. N Engl J Med 2021. doi:10.1056/NEJMoa2105290

[8] Voysey M, Clemens SAC, Madhi SA, et al. Safety and efficacy of the ChAdOx1 nCoV-19 vaccine (AZD1222) against SARS-CoV-2: an interim analysis of four randomised controlled trials in Brazil, South Africa, and the UK. Lancet 2021;397:99-111. doi:10.1016/S01406736(20)32661-1

[9] Polack FP, Thomas SJ, Kitchin N, et al. Safety and Efficacy of the BNT162b2 mRNA Covid-19 Vaccine. N Engl J Med 2020;383:2603-2615. doi:10.1056/NEJMoa2034577

[10] Baden LR, El Sahly HM, Essink B, et al. Efficacy and Safety of the mRNA-1273 SARS-CoV-2 Vaccine. N Engl J Med 2021;384:403-416. doi:10.1056/NEJMoa2035389

[11] Pritchard E, Matthews PC, Stoesser N, et al. Impact of vaccination on new SARS-CoV-2 infections in the United Kingdom. Nat Med 2021;27:1370-1378. doi:10.1038/s41591-021-015487

[12] Menni C, Klaser K, May A, et al. Vaccine side-effects and SARS-CoV-2 infection after vaccination in users of the COVID Symptom Study app in the UK: a prospective observational study. Lancet Infect Dis 2021,21:939-949. doi:10.1016/S1473-3099(21)00224-3

[13] Harris RJ, Hall JA, Zaidi A. "Effect of Vaccination on Household Transmission of SARS-CoV-2 in England. N Engl J Med 2021;385:759-760. doi:10.1056/NEJMc2107717

[14] Lopez Bernal J, Andrews N, Gower C, et al. Effectiveness of the Pfizer-BioNTech and OxfordAstraZeneca vaccines on covid-19 related symptoms, hospital admissions, and mortality in older adults in England: test negative case-control study. BMJ 2021;373:n1088.

doi:10.1136/bmj.n1088

[15] Office for National Statistics. Deaths involving COVID-19 by vaccination status, England: deaths occurring between 2 January and 24 September 2021. 2021.

https://www.ons.gov.uk/peoplepopulationandcommunity/birthsdeathsandmarriages/deaths/bulleti ns/deathsinvolvingcovid19byvaccinationstatusengland/deathsoccurringbetween2januaryand24s eptember2021 
medRxiv preprint doi: https://doi.org/10.1101/2021.12.09.21267516; this version posted December $9,2021$. The copyright holder for this preprint (which was not certified by peer review) is the author/funder, who has granted medRxiv a license to display the preprint in

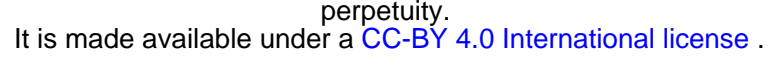

[16] Antonelli M, Penfold RS, Merino J, et al. Risk factors and disease profile of post-vaccination SARS-CoV-2 infection in UK users of the COVID Symptom Study app: a prospective, community-based, nested, case-control study. Lancet Infect Dis 2021. doi:10.1016/S14733099(21)00460-6

[17] Arnold DT, Milne A, Samms E, Stadon L, Maskell NA, Hamilton FW. Are vaccines safe in patients with Long COVID? A prospective observational study. medRxiv [Preprint] 2021. https://www.medrxiv.org/content/10.1101/2021.03.11.21253225v3

[18] Tran V-T, Perrodeau E, Saldanha J, Pane I, Ravaud P. Efficacy of COVID-19 Vaccination on the Symptoms of Patients With Long COVID: A Target Trial Emulation Using Data From the ComPaRe e-Cohort in France. SSRN [Preprint] 2021.

https://papers.ssrn.com/sol3/papers.cfm?abstract_id=3932953

[19] Sherwood O, Strain D, Rossman J. The impact of COVID vaccination on symptoms of Long Covid. An international survey of 900 people with lived experience. 2021. https://3ca26cd7266e-4609-b25f6f3d1497c4cf.filesusr.com/ugd/8bd4fe_a338597f76bf4279a851a7a4cb0e0a74.pdf

[20] Office for National Statistics. COVID-19 Infection Survey: methods and further information. 2021. https://www.ons.gov.uk/peoplepopulationandcommunity/healthandsocialcare/conditionsanddisea ses/methodologies/covid19infectionsurveypilotmethodsandfurtherinformation

[21] Michelen M, Manoharan L, Elkheir N, et al. Characterising long COVID: a living systematic review. BMJ Glob Health 2021;6:e005427. doi:10.1136/bmjgh-2021-005427

[22] World Health Organisation. A clinical case definition of post COVID-19 condition by a Delphi consensus, 6 October 2021 . 2021. https://www.who.int/publications-detail-redirect/WHO-2019nCoV-Post_COVID-19_condition-Clinical_case_definition-2021.1

[23] Public Health England. COVID-19: the green book, chapter 14a. 2020. https://www.gov.uk/government/publications/covid-19-the-green-book-chapter-14a

[24] Austin PC. "Balance diagnostics for comparing the distribution of baseline covariates between treatment groups in propensity-score matched samples. Stat Med 2009;28:3083-3107. doi:10.1002/sim.3697

[25] Office for National Statistics. Coronavirus (COVID-19) Infection Survey technical article: waves and lags of COVID-19 in England, June 2021. 2021.

https://www.ons.gov.uk/peoplepopulationandcommunity/healthandsocialcare/conditionsanddisea ses/articles/coronaviruscovid19infectionsurveytechnicalarticle/wavesandlagsofcovid19inenglandj une2021

[26] Centres for Disease Control and Prevention. Symptoms of COVID-19. 2021. https://www.cdc.gov/coronavirus/2019-ncov/symptoms-testing/symptoms.html

[27] Massey D, Berrent D, Akrami A, et al. Change in Symptoms and Immune Response in People with Post-Acute Sequelae of SARS-Cov-2 Infection (PASC) After SARS-Cov-2 Vaccination. medRviv [Preprint] 2021. https://www.medrxiv.org/content/10.1101/2021.07.21.21260391v2

[28] García-Abellán J, Padilla S, Fernández-González M, et al. Antibody Response to SARS-CoV-2 is Associated with Long-term Clinical Outcome in Patients with COVID-19: a Longitudinal Study. J Clin Immunol 2021;41:1490-1501. doi:10.1007/s10875-021-01083-7 
Table 1. Characteristics of study participants at their final follow-up visit, stratified by vaccine type

\begin{tabular}{|c|c|c|c|c|c|}
\hline Characteristic & Category & $\begin{array}{l}\text { Full sample } \\
(n=28,356)\end{array}$ & $\begin{array}{r}\text { mRNA vaccinated } \\
(n=12,859)\end{array}$ & $\begin{array}{r}\text { Vector vaccinated } \\
(n=15,497)\end{array}$ & $\begin{array}{r}\text { Standardized } \\
\text { difference }(\%)\end{array}$ \\
\hline \multicolumn{2}{|c|}{ Time since infection (days), mean (SD) } & $308.9(129.0)$ & $314.9(132.9)$ & $304.0(125.4)$ & 8.4 \\
\hline \multicolumn{2}{|c|}{ Time since first vaccination (days), mean (SD) } & $130.7(55.9)$ & $118.0(67.8)$ & $141.2(40.7)$ & -41.5 \\
\hline \multicolumn{2}{|l|}{ Age (years), mean (SD) } & $45.9(13.6)$ & $40.1(14.1)$ & $50.7(11.1)$ & -83.4 \\
\hline \multirow[t]{2}{*}{ Sex, $n(\%)$} & Male & $12,596(44.4)$ & $5,466(42.5)$ & $7,130(46.0)$ & -7.1 \\
\hline & Female & $15,760(55.6)$ & $7,393(57.5)$ & $8,367(54.0)$ & 7.1 \\
\hline \multirow[t]{2}{*}{ Ethnic group, $n(\%)$} & White & $25,141(88.7)$ & $11,097(86.3)$ & $14,044(90.6)$ & -13.6 \\
\hline & Non-white & $3,215(11.3)$ & $1,762(13.7)$ & $1,453(9.4)$ & 13.6 \\
\hline \multirow[t]{12}{*}{ Region or country, $n(\%)$} & North East England & $1,133(4.0)$ & $524(4.1)$ & $609(3.9)$ & 0.7 \\
\hline & North West England & $3,990(14.1)$ & $1,774(13.8)$ & $2,216(14.3)$ & -1.4 \\
\hline & Yorkshire and the Humber & $2,430(8.6)$ & $1,028(8.0)$ & $1,402(9.0)$ & -3.8 \\
\hline & East Midlands & $1,755(6.2)$ & $710(5.5)$ & $1,045(6.7)$ & -5.1 \\
\hline & West Midlands & $2,204(7.8)$ & $917(7.1)$ & $1,287(8.3)$ & -4.4 \\
\hline & East of England & $2,447(8.6)$ & $1,044(8.1)$ & $1,403(9.1)$ & -3.3 \\
\hline & London & $6,942(24.5)$ & $3,470(27.0)$ & 3,472 (22.4) & 10.6 \\
\hline & South East England & $2,919(10.3)$ & $1,208(9.4)$ & $1,711(11.0)$ & -5.4 \\
\hline & South West England & $1,276(4.5)$ & $580(4.5)$ & $696(4.5)$ & 0.1 \\
\hline & Northern Ireland & $657(2.3)$ & $421(3.3)$ & $236(1.5)$ & 11.5 \\
\hline & Scotland & $1,376(4.9)$ & $620(4.8)$ & 756 (4.9) & -0.3 \\
\hline & Wales & $1,227(4.3)$ & $563(4.4)$ & $664(4.3)$ & 0.5 \\
\hline \multirow{5}{*}{$\begin{array}{l}\text { Area deprivation quintile } \\
\text { group, } n(\%)\end{array}$} & 1 (most deprived) & $3,825(13.5)$ & $1,779(13.8)$ & 2,046 (13.2) & 1.8 \\
\hline & & $5,392(19.0)$ & $2,671(20.8)$ & $2,721(17.6)$ & 8.2 \\
\hline & 3 & $5,857(20.7)$ & $2,633(20.5)$ & 3,224 (20.8) & -0.8 \\
\hline & 4 & $6,474(22.8)$ & $2,914(22.7)$ & $3,560(23.0)$ & -0.7 \\
\hline & 5 (least deprived) & $6,808(24.0)$ & $2,862(22.3)$ & $3,946(25.5)$ & -7.5 \\
\hline $\begin{array}{l}\text { Patient-facing health or } \\
\text { social care worker, } n(\%)\end{array}$ & Yes & $3,190(11.2)$ & $2,198(17.1)$ & $992(6.4)$ & 33.7 \\
\hline Health conditions, $n(\%)$ & Yes & $3,851(13.6)$ & $1,531(11.9)$ & $2,320(15.0)$ & -9.0 \\
\hline $\begin{array}{l}\text { Hospitalisation with acute } \\
\text { COVID-19, } n(\%)\end{array}$ & Yes & $900(3.2)$ & $359(2.8)$ & $541(3.5)$ & -4.0 \\
\hline
\end{tabular}

Notes: mRNA: messenger ribonucleic acid; SD: standard deviation. The study sample size did not permit disaggregation of ethnicity beyond white and nonwhite groups. Area deprivation was based on the English Indices of Deprivation 2019, the Welsh Index of Multiple Deprivation 2019, the Scottish Index of Multiple Deprivation 2020, and the Northern Ireland Multiple Deprivation Measure 2017. Health conditions were self-reported rather than clinically diagnosed based on the survey question: "Do you have any physical or mental health conditions or illnesses lasting or expected to last 12 months or more (excluding any long-lasting COVID-19 symptoms)?" Hospitalisation with acute COVID-19 was self-reported rather than derived from medical records. 
Table 2. Estimated time trajectories of Long Covid from infection, and changes in trajectories following COVID-19 vaccination

\begin{tabular}{|c|c|c|c|c|c|}
\hline Outcome & Variable & Estimate & SE & P-value & Odds ratio (95\% Cl) \\
\hline $\begin{array}{l}\text { Long Covid of any } \\
\text { severity }\end{array}$ & $\begin{array}{l}\text { Time trajectory (per week) } \\
\text { First vaccination (change in level) } \\
\text { Second vaccination (change in level) } \\
\text { Time since first vaccination (per week) } \\
\text { Time since second vaccination (per week) }\end{array}$ & $\begin{array}{r}-0.003 \\
-0.137 \\
-0.092 \\
0.006 \\
-0.011\end{array}$ & $\begin{array}{l}0.003 \\
0.035 \\
0.031 \\
0.005 \\
0.005\end{array}$ & $\begin{array}{r}0.25 \\
<0.001 \\
0.003 \\
0.21 \\
0.03\end{array}$ & $\begin{array}{l}0.997(0.991 \text { to } 1.002) \\
0.872(0.814 \text { to } 0.934) \\
0.912(0.859 \text { to } 0.969) \\
1.006(0.996 \text { to } 1.016) \\
0.989(0.979 \text { to } 0.999)\end{array}$ \\
\hline $\begin{array}{l}\text { Activity-limiting } \\
\text { Long Covid }\end{array}$ & $\begin{array}{l}\text { Time trajectory (per week) } \\
\text { First vaccination (change in level) } \\
\text { Second vaccination (change in level) } \\
\text { Time since first vaccination (per week) } \\
\text { Time since second vaccination (per week) }\end{array}$ & $\begin{array}{r}0.003 \\
-0.131 \\
-0.096 \\
0.006 \\
-0.013 \\
\end{array}$ & $\begin{array}{l}0.004 \\
0.044 \\
0.038 \\
0.006 \\
0.006\end{array}$ & $\begin{array}{r}0.44 \\
0.003 \\
0.01 \\
0.35 \\
0.03 \\
\end{array}$ & $\begin{array}{l}1.003(0.996 \text { to } 1.010) \\
0.877(0.805 \text { to } 0.955) \\
0.909(0.844 \text { to } 0.979) \\
1.006(0.994 \text { to } 1.018) \\
0.987(0.976 \text { to } 0.998) \\
\end{array}$ \\
\hline
\end{tabular}

Notes: Cl: confidence interval; SE: standard error. Estimates and standard errors are on the logit scale. Odds ratios for 'time since first/second vaccination' represent modification of the time trajectory. Estimates and odds ratios are adjusted for age, sex, white or non-white ethnicity, region/country, area deprivation quintile group, health status, whether a patient-facing health or social care worker, whether hospitalised with acute COVID-19, and calendar time of infection. 
Table 3. Estimated time trajectories of Long Covid from infection, and changes in trajectories following COVID-19 vaccination, moderated by vaccine type

\begin{tabular}{|c|c|c|c|c|c|}
\hline Outcome & Variable & Estimate & SE & P-value & Odds ratio (95\% Cl) \\
\hline \multirow{10}{*}{$\begin{array}{l}\text { Long Covid of } \\
\text { any severity }\end{array}$} & Time trajectory (per week) & -0.004 & 0.003 & 0.19 & 0.996 (0.990 to 1.002$)$ \\
\hline & First vaccination (change in level) & -0.093 & 0.055 & 0.09 & $0.911(0.818$ to 1.014$)$ \\
\hline & Second vaccination (change in level) & -0.093 & 0.051 & 0.07 & 0.911 (0.824 to 1.007$)$ \\
\hline & Time since first vaccination (per week) & 0.000 & 0.008 & 0.95 & $1.000(0.985$ to 1.016$)$ \\
\hline & Time since second vaccination (per week) & -0.004 & 0.008 & 0.65 & 0.996 (0.980 to 1.013$)$ \\
\hline & Vaccine type: adenovirus vector (versus mRNA) & 0.046 & 0.055 & 0.40 & 1.048 (0.941 to 1.166$)$ \\
\hline & First vaccination interacted with type & -0.069 & 0.067 & 0.31 & 0.934 (0.818 to 1.066$)$ \\
\hline & Second vaccination interacted with type & 0.002 & 0.064 & 0.97 & $1.002(0.883$ to 1.137$)$ \\
\hline & Time since first vaccination interacted with type & 0.009 & 0.009 & 0.33 & 1.009 (0.991 to 1.028$)$ \\
\hline & Time since second vaccination interacted with type & -0.010 & 0.010 & 0.33 & $0.990(0.970$ to 1.010$)$ \\
\hline \multirow{10}{*}{$\begin{array}{l}\text { Activity-limiting } \\
\text { Long Covid }\end{array}$} & Time trajectory (per week) & 0.002 & 0.004 & 0.56 & $1.002(0.995$ to 1.009$)$ \\
\hline & First vaccination (change in level) & -0.154 & 0.070 & 0.03 & 0.857 (0.747 to 0.984$)$ \\
\hline & Second vaccination (change in level) & -0.026 & 0.064 & 0.68 & $0.974(0.860$ to 1.103$)$ \\
\hline & Time since first vaccination (per week) & 0.003 & 0.010 & 0.77 & 1.003 (0.984 to 1.022$)$ \\
\hline & Time since second vaccination (per week) & -0.013 & 0.010 & 0.21 & 0.987 (0.968 to 1.007$)$ \\
\hline & Vaccine type: adenovirus vector (versus mRNA) & 0.042 & 0.069 & 0.54 & 1.043 (0.911 to 1.195$)$ \\
\hline & First vaccination interacted with type & 0.045 & 0.087 & 0.60 & 1.046 (0.883 to 1.240$)$ \\
\hline & Second vaccination interacted with type & -0.116 & 0.080 & 0.15 & $0.890(0.761$ to 1.041$)$ \\
\hline & Time since first vaccination interacted with type & 0.004 & 0.012 & 0.75 & $1.004(0.981$ to 1.027$)$ \\
\hline & Time since second vaccination interacted with type & 0.004 & 0.013 & 0.73 & $1.004(0.980$ to 1.029$)$ \\
\hline
\end{tabular}

Notes: Cl: confidence interval; mRNA: messenger ribonucleic acid; SE: standard error. Estimates and standard errors are on the logit scale. Odds ratios for 'time since first/second vaccination' represent modification of the time trajectory. Odds ratios for 'first/second vaccination interacted with type' represent modification of the change in level after first/second vaccination by vaccine type. Odds ratios for 'time since first/second vaccination interacted with type' represent modification of the time trajectory, modified by vaccine type. Estimates and odds ratios are adjusted for age, sex, white or non-white ethnicity, region/country, area deprivation quintile group, health status, whether a patient-facing health or social care worker, whether hospitalised with acute COVID19 , and calendar time of infection. 
medRxiv preprint doi: https://doi.org/10.1101/2021.12.09.21267516; this version posted December 9, 2021. The copyright holder for this preprint (which was not certified by peer review) is the author/funder, who has granted medRxiv a license to display the preprint in

perpetuity.
It is made available under a CC-BY 4.0 International license .

Figure 1. Modelled probabilities of Long Covid for a hypothetical study participant who received their first vaccination 24 weeks after infection and their second vaccination 12 weeks later

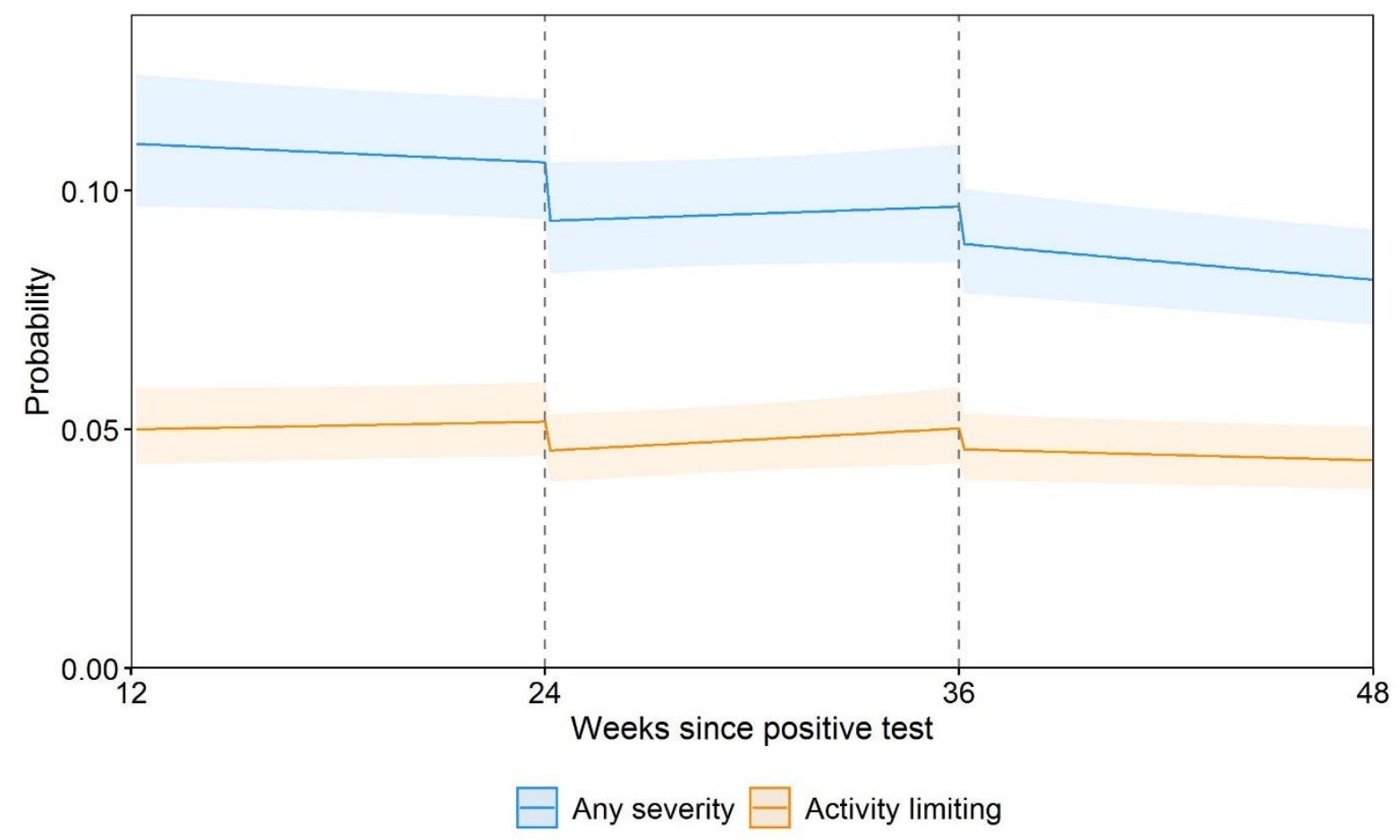

Notes: Probabilities are shown for a participant of approximately mean age (50 years) and in the modal group for other covariates (female, white, living in London, in an area in the least deprived quintile group, not a patient-facing health or social care worker, no pre-existing health conditions, not hospitalised at the acute phase of infection, and infected on 7 September 2020). While the estimated probabilities are specific to this profile, the proportional changes in probabilities after vaccination do not vary across characteristics and can therefore be generalised to other profiles. Dashed lines indicate the timing of vaccination. Shaded areas are $95 \%$ confidence intervals. 
medRxiv preprint doi: https://doi.org/10.1101/2021.12.09.21267516; this version posted December 9, 2021. The copyright holder for this preprint (which was not certified by peer review) is the author/funder, who has granted medRxiv a license to display the preprint in perpetuity.

It is made available under a CC-BY 4.0 International license.

Figure 2. Modelled probabilities of Long Covid for hypothetical study participants who received their first adenovirus vector or mRNA vaccination 24 weeks after infection and their second vaccination 12 weeks later

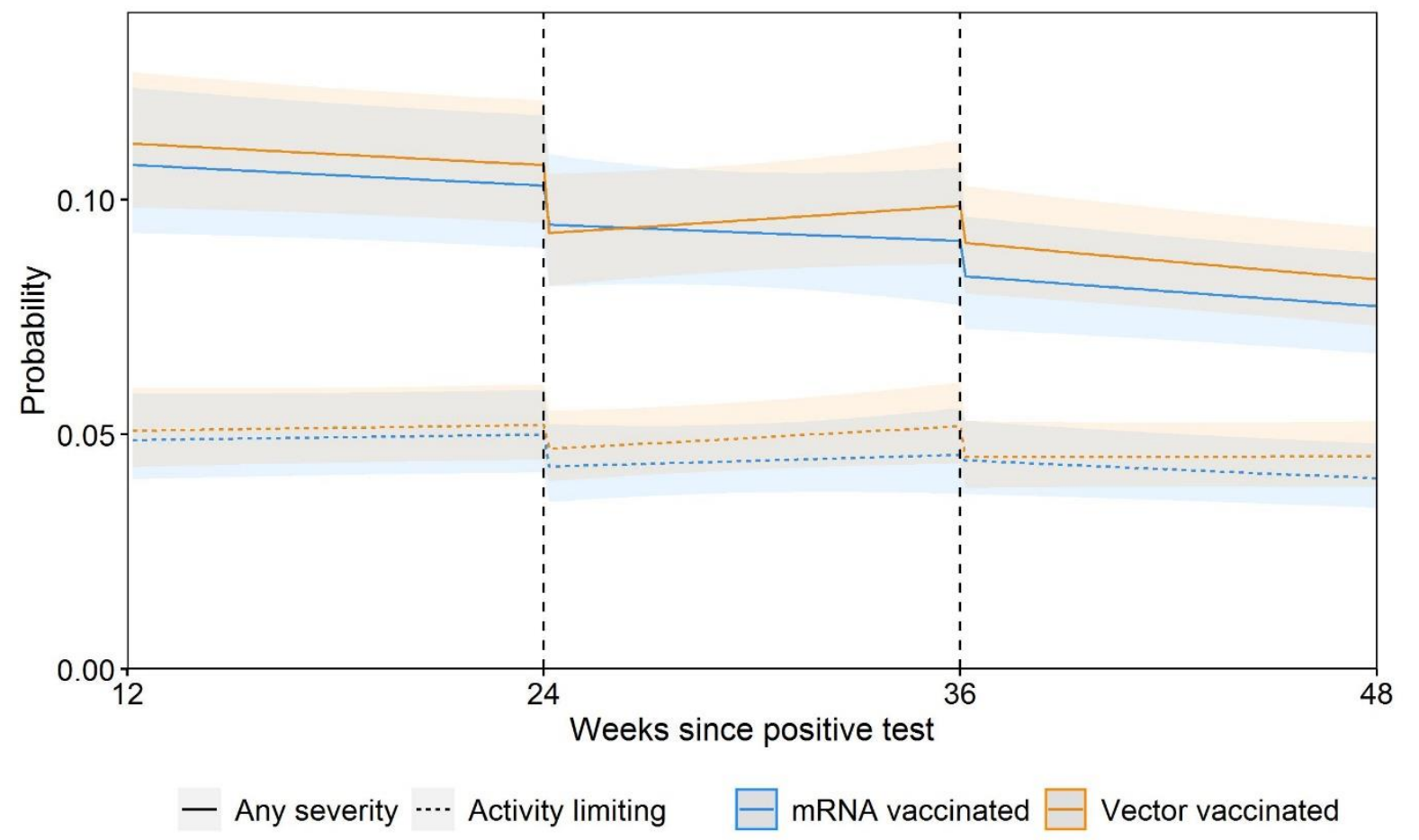

Notes: mRNA: messenger ribonucleic acid. Probabilities are shown for a participant of approximately mean age (50 years) and in the modal group for other covariates (female, white, living in London, in an area in the least deprived quintile group, not a patient-facing health or social care worker, no pre-existing health conditions, not hospitalised at the acute phase of infection, and infected on 7 September 2020). While the estimated probabilities are specific to this profile, the proportional changes in probabilities after vaccination do not vary across characteristics and can therefore be generalised to other profiles. Dashed lines indicate the timing of vaccination. Shaded areas are $95 \%$ confidence intervals. 
medRxiv preprint doi: https://doi.org/10.1101/2021.12.09.21267516; this version posted December 9, 2021. The copyright holder for this preprint (which was not certified by peer review) is the author/funder, who has granted medRxiv a license to display the preprint in

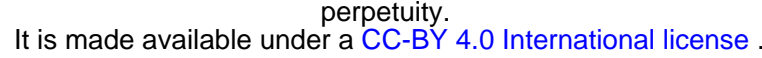

Figure 3. Modelled probabilities of individual Long Covid symptoms for a hypothetical study participant who received their first vaccination 24 weeks after infection and their second vaccination 12 weeks later
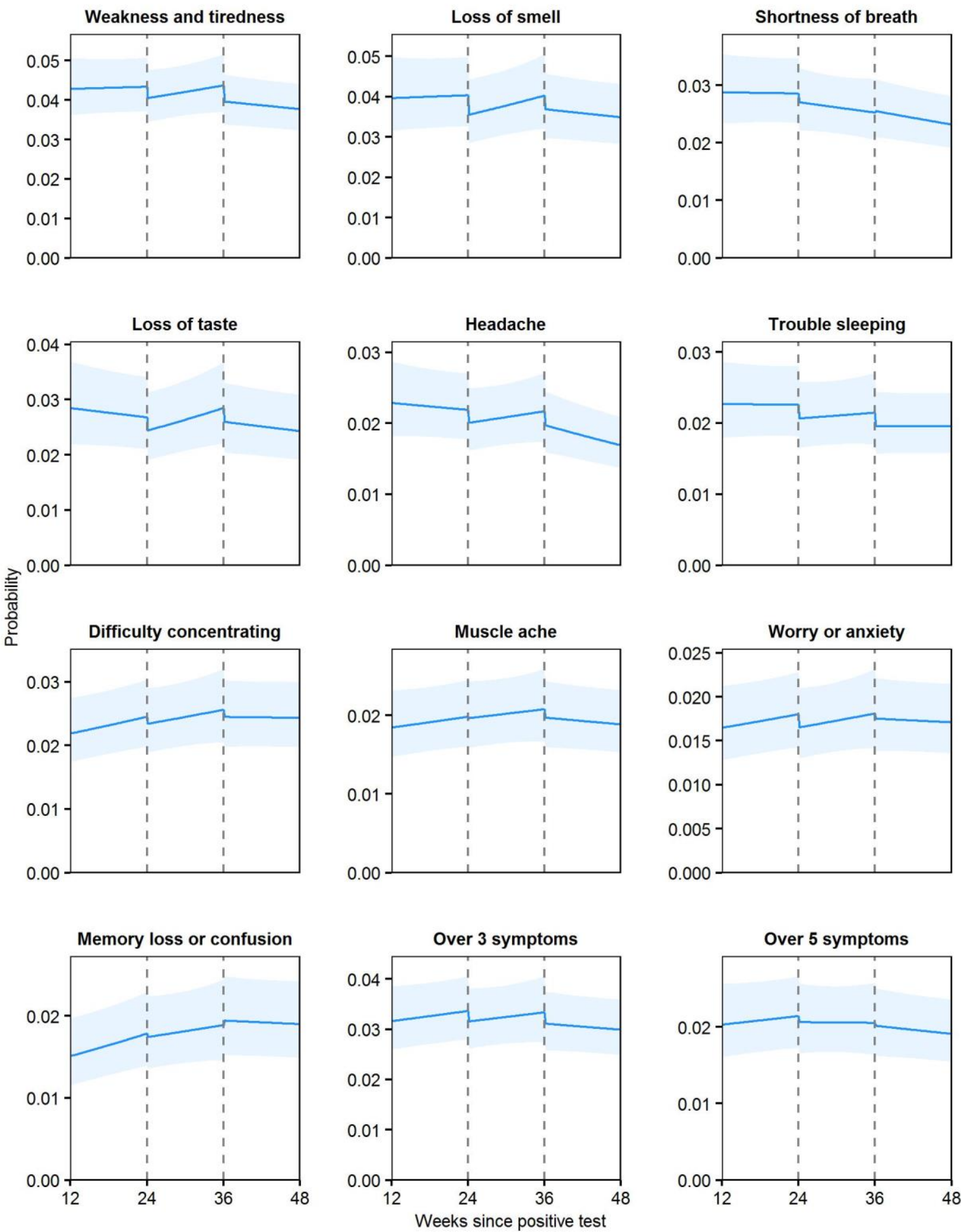

Notes: Top 10 most frequently reported symptoms ordered by modelled probability at 12 weeks postinfection. Probabilities are shown for a participant of approximately mean age (50 years) and in the modal group for other covariates (female, white, living in London, in an area in the least deprived quintile group, not a patient-facing health or social care worker, no pre-existing health conditions, not hospitalised at the acute phase of infection, and infected on 7 September 2020). While the estimated probabilities are specific to this profile, the proportional changes in probabilities after vaccination do not vary across characteristics and can therefore be generalised to other profiles. Dashed lines indicate the timing of vaccination. Shaded areas are $95 \%$ confidence intervals. 
medRxiv preprint doi: https://doi.org/10.1101/2021.12.09.21267516; this version posted December 9, 2021. The copyright holder for this preprint (which was not certified by peer review) is the author/funder, who has granted medRxiv a license to display the preprint in perpetuity.

Supplementary Table 1. Number and percentage of households invited to participate in the Coronavirus (COVID-19) Infection Survey who subsequently enrolled, by country and phase

\begin{tabular}{|l|r|r|r|r|}
\hline Phase & England & Wales & Northern Ireland & Scotland \\
\hline Initial invitation & $10,266(51 \%)$ & $7,017(40 \%)$ & $7,084(43 \%)$ & $\mathrm{N} / \mathrm{A}$ \\
\hline Extension period & $39,345(43 \%)$ & $\mathrm{N} / \mathrm{A}$ & $\mathrm{N} / \mathrm{A}$ & $\mathrm{N} / \mathrm{A}$ \\
\hline AddressBase & $167,890(12 \%)$ & $7,013(14 \%)$ & $\mathrm{N} / \mathrm{A}$ & $22,131(13 \%)$ \\
\hline
\end{tabular}

Notes: The initial invitation phase started on 26 April 2020 in England, 29 June 2020 in Wales, and 26 July 2020 in Northern Ireland. The extension period started on 31 May 2020 in England. Sampling from AddressBase started on 13 July 2020 in England, 5 October 2020 in Wales, and 14 September 2020 in Scotland. Enrolment rates as of 22 October 2021, taken from the technical dataset accompanying the Coronavirus (COVID-19) Infection Survey:

https://www.ons.gov.uk/peoplepopulationandcommunity/healthandsocialcare/conditionsanddiseases/d atasets/covid19infectionsurveytechnicaldata 
medRxiv preprint doi: https://doi.org/10.1101/2021.12.09.21267516; this version posted December 9, 2021. The copyright holder for this preprint (which was not certified by peer review) is the author/funder, who has granted medRxiv a license to display the preprint in perpetuity.

It is made available under a CC-BY 4.0 International license .

Supplementary Table 2. Long Covid symptoms included on the Coronavirus (COVID-19) Infection Survey

\begin{tabular}{|l|}
\hline Symptom \\
\hline 1. Fever \\
\hline 2. Headache \\
\hline 3. Muscle ache \\
\hline 4. Weakness/tiredness \\
\hline 5. Nausea/vomiting \\
\hline 6. Abdominal pain \\
\hline 7. Diarrhoea \\
\hline 8. Loss of appetite \\
\hline 9. Loss of taste \\
\hline 10. Loss of smell \\
\hline 11. Sore throat \\
\hline 12. Cough \\
\hline 13. Shortness of breath \\
\hline 14. Chest pain \\
\hline 15. Palpitations \\
\hline 16. Vertigo/dizziness \\
\hline 17. Worry/anxiety \\
\hline 18. Low mood/not enjoying anything \\
\hline 19. Trouble sleeping \\
\hline 20. Memory loss or confusion \\
\hline 21. Difficulty concentrating \\
\hline
\end{tabular}

Notes: All participants who responded positively to the survey question "Would you describe yourself as having 'long COVID', that is, you are still experiencing symptoms more than 4 weeks after you first had COVID-19, that are not explained by something else?" were then asked "Do you have any of the following symptoms as part of your experience of long COVID? Please include any pre-existing symptoms which long COVID has made worse (answer Yes or No for each one)." 
medRxiv preprint doi: https://doi.org/10.1101/2021.12.09.21267516; this version posted December 9, 2021. The copyright holder for this preprint (which was not certified by peer review) is the author/funder, who has granted medRxiv a license to display the preprint in perpetuity.

It is made available under a CC-BY 4.0 International license.

Supplementary Table 3. Description of covariates included in the analysis

\begin{tabular}{|l|l|}
\hline Covariate & Specification in analysis \\
\hline Time since infection date (days) & Linear \\
\hline Calendar time of infection (days) & $\begin{array}{l}\text { Restricted cubic spline with boundary knots at the } 10^{\text {th }} \text { and } 90^{\text {th }} \\
\text { percentiles and an interior knot at the } 50^{\text {th }} \text { percentile }\end{array}$ \\
\hline Age (years) & $\begin{array}{l}\text { Restricted cubic spline with boundary knots at the } 10^{\text {th }} \text { and } 90^{\text {th }} \\
\text { percentiles and an interior knot at the } 50^{\text {th }} \text { percentile }\end{array}$ \\
\hline Sex & Binary dummy variable (male [reference], female) \\
\hline Ethnic group & Binary dummy variable (white [reference], non-white) \\
\hline Region or country & $\begin{array}{l}\text { Categorical variable (North East England, North West England, } \\
\text { Yorkshire and the Humber, East Midlands, West Midlands, East } \\
\text { of England, London [reference], South East England, South } \\
\text { West England, Northern Ireland, Scotland, Wales) }\end{array}$ \\
\hline Area deprivation quintile group & $\begin{array}{l}\text { Categorical variable (1, most deprived [reference], to 5, least } \\
\text { deprived) }\end{array}$ \\
\hline $\begin{array}{l}\text { Patient-facing health or social } \\
\text { care worker }\end{array}$ & Binary dummy variable (no [reference], yes) \\
\hline $\begin{array}{l}\text { Health conditions (excluding } \\
\text { those attributed to COVID-19) }\end{array}$ & Binary dummy variable (no [reference], yes) \\
\hline $\begin{array}{l}\text { Hospitalisation with acute } \\
\text { COVID-19 }\end{array}$ & Binary dummy variable (no [reference], yes) \\
\hline
\end{tabular}

Notes: Calendar time of infection was calculated as the number of days from 24 January 2020 (when the first SARS-CoV-2 cases were reported in the UK) and the infection date. The study sample size did not permit disaggregation of ethnicity beyond white and non-white groups. Area deprivation was based on the English Indices of Deprivation 2019, the Welsh Index of Multiple Deprivation 2019, the Scottish Index of Multiple Deprivation 2020, and the Northern Ireland Multiple Deprivation Measure 2017. Health conditions were self-reported rather than clinically diagnosed based on the survey question: "Do you have any physical or mental health conditions or illnesses lasting or expected to last 12 months or more (excluding any long-lasting COVID-19 symptoms)?" Hospitalisation with acute COVID-19 was self-reported rather than derived from medical records. 
medRxiv preprint doi: https://doi.org/10.1101/2021.12.09.21267516; this version posted December 9, 2021. The copyright holder for this preprint (which was not certified by peer review) is the author/funder, who has granted medRxiv a license to display the preprint in perpetuity.

It is made available under a CC-BY 4.0 International license.

Supplementary Table 4. Number and percentage of included participants who received their first and second vaccinations during (rather than before) the follow-up period, stratified by age group and health conditions at last follow-up visit

\begin{tabular}{|l|l|r|r|r|}
\hline $\begin{array}{l}\text { Age } \\
\text { group }\end{array}$ & $\begin{array}{l}\text { Health } \\
\text { conditions }\end{array}$ & Total & $\begin{array}{r}\text { Received first vaccination } \\
\text { during follow-up }\end{array}$ & $\begin{array}{r}\text { Received second } \\
\text { vaccination during follow-up }\end{array}$ \\
\hline $\begin{array}{l}18 \text { to } 29 \\
\text { years }\end{array}$ & Ye & 3,789 & $2,367(62.5 \%)$ & $1,666(44.0 \%)$ \\
\hline 30 to 39 & No & 385 & $197(51.2 \%)$ & $213(55.3 \%)$ \\
years & Yes & 5,902 & $2,921(59.6 \%)$ & $3,264(66.6 \%)$ \\
\hline 40 to 49 & No & $238(44.7 \%)$ & $359(67.4 \%)$ \\
years & Yes & 6975 & $2,923(51.5 \%)$ & $4,325(76.2 \%)$ \\
\hline 50 to 59 & No & 5,829 & $291(41.6 \%)$ & $534(76.4 \%)$ \\
years & Yes & 1,112 & $2,275(39.0 \%)$ & $4,719(81.0 \%)$ \\
\hline 60 to 70 & No & 4,310 & $394(35.4 \%)$ & $888(79.9 \%)$ \\
years & Yes & 1,122 & $1,088(25.2 \%)$ & $3,507(81.4 \%)$ \\
\hline
\end{tabular}

Notes: The study sample included only people aged under 70 years at their first visit during the followup period, and a small number of participants turned 70 before their last visit, hence the upper boundary of the final age group is 70 rather than 69 years. Health conditions were self-reported rather than clinically diagnosed based on the survey question: "Do you have any physical or mental health conditions or illnesses lasting or expected to last 12 months or more (excluding any long-lasting COVID-19 symptoms)?" 
Supplementary Table 5a. Interactions between vaccination and personal characteristics: Long Covid of any severity, first vaccination

\begin{tabular}{|c|c|c|c|c|c|c|c|}
\hline Modifier (comparator) & Exposure & Group & Estimate & SE & P-value & H-B p-value & B-Y p-value \\
\hline \multirow{2}{*}{$\begin{array}{l}\text { Vaccine type (mRNA } \\
\text { vaccine) }\end{array}$} & First vaccination (change in level) & Adenovirus vector & -0.069 & 0.067 & 0.31 & $>0.99$ & $>0.99$ \\
\hline & Time since first vaccination (weeks) & Adenovirus vector & 0.009 & 0.009 & 0.33 & $>0.99$ & $>0.99$ \\
\hline \multirow{8}{*}{$\begin{array}{l}\text { Age group (18 to } 29 \\
\text { years) }\end{array}$} & First vaccination (change in level) & 30 to 39 years & 0.157 & 0.132 & 0.23 & $>0.99$ & $>0.99$ \\
\hline & & 40 to 49 years & 0.195 & 0.129 & 0.13 & $>0.99$ & $>0.99$ \\
\hline & & 50 to 59 years & 0.136 & 0.131 & 0.30 & $>0.99$ & $>0.99$ \\
\hline & & 60 to 70 years & -0.021 & 0.143 & 0.89 & $>0.99$ & $>0.99$ \\
\hline & Time since first vaccination (weeks) & 30 to 39 years & -0.028 & 0.021 & 0.18 & $>0.99$ & $>0.99$ \\
\hline & & 40 to 49 years & -0.024 & 0.020 & 0.24 & $>0.99$ & $>0.99$ \\
\hline & & 50 to 59 years & -0.029 & 0.020 & 0.15 & $>0.99$ & $>0.99$ \\
\hline & & 60 to 70 years & -0.024 & 0.020 & 0.24 & $>0.99$ & $>0.99$ \\
\hline \multirow{2}{*}{ Sex (male) } & First vaccination (change in level) & Female & -0.044 & 0.068 & 0.52 & $>0.99$ & $>0.99$ \\
\hline & Time since first vaccination (weeks) & Female & 0.016 & 0.009 & 0.08 & $>0.99$ & $>0.99$ \\
\hline \multirow[t]{2}{*}{ Ethnic group (white) } & First vaccination (change in level) & Non-white & 0.059 & 0.121 & 0.62 & $>0.99$ & $>0.99$ \\
\hline & Time since first vaccination (weeks) & Non-white & 0.005 & 0.016 & 0.78 & $>0.99$ & $>0.99$ \\
\hline \multirow{8}{*}{$\begin{array}{l}\text { Area deprivation quintile } \\
\text { group }(1, \text { most deprived) }\end{array}$} & First vaccination (change in level) & 2 & 0.098 & 0.115 & 0.40 & $>0.99$ & $>0.99$ \\
\hline & & 3 & -0.123 & 0.109 & 0.26 & $>0.99$ & $>0.99$ \\
\hline & & 4 & -0.102 & 0.109 & 0.35 & $>0.99$ & $>0.99$ \\
\hline & & 5 (least deprived) & 0.064 & 0.108 & 0.55 & $>0.99$ & $>0.99$ \\
\hline & Time since first vaccination (weeks) & 2 & -0.012 & 0.015 & 0.40 & $>0.99$ & $>0.99$ \\
\hline & & 3 & 0.012 & 0.014 & 0.40 & $>0.99$ & $>0.99$ \\
\hline & & 4 & 0.006 & 0.014 & 0.65 & $>0.99$ & $>0.99$ \\
\hline & & 5 (least deprived) & -0.029 & 0.014 & 0.046 & $>0.99$ & $>0.99$ \\
\hline \multirow[t]{2}{*}{ Health conditions (No) } & First vaccination (change in level) & Yes & -0.015 & 0.080 & 0.85 & $>0.99$ & $>0.99$ \\
\hline & Time since first vaccination (weeks) & Yes & 0.007 & 0.009 & 0.45 & $>0.99$ & $>0.99$ \\
\hline \multirow{2}{*}{$\begin{array}{l}\text { Hospitalised at acute } \\
\text { phase of infection (No) }\end{array}$} & First vaccination (change in level) & Yes & 0.035 & 0.141 & 0.80 & $>0.99$ & $>0.99$ \\
\hline & Time since first vaccination (weeks) & Yes & 0.005 & 0.015 & 0.76 & $>0.99$ & $>0.99$ \\
\hline \multirow{4}{*}{$\begin{array}{l}\text { Days from infection to } \\
\text { vaccination (restricted } \\
\text { cubic spline) }\end{array}$} & First vaccination (change in level) & First term & -0.527 & 0.299 & 0.08 & $>0.99$ & $>0.99$ \\
\hline & & Second term & 0.013 & 0.087 & 0.88 & $>0.99$ & $>0.99$ \\
\hline & Time since first vaccination (weeks) & First term & 0.051 & 0.023 & 0.03 & $>0.99$ & $>0.99$ \\
\hline & & Second term & 0.016 & 0.011 & 0.15 & $>0.99$ & $>0.99$ \\
\hline
\end{tabular}

Notes: B-Y: Benjamini-Yekutieli; H-B: Holm-Bonferroni; mRNA: messenger ribonucleic acid; SE: standard error. 
Supplementary Table 5b. Interactions between vaccination and personal characteristics: Long Covid of any severity, second vaccination

\begin{tabular}{|c|c|c|c|c|c|c|c|}
\hline Modifier (comparator) & Exposure & Group & Estimate & SE & P-value & H-B p-value & B-Y p-value \\
\hline \multirow{2}{*}{$\begin{array}{l}\text { Vaccine type (mRNA } \\
\text { vaccine) }\end{array}$} & Second vaccination (change in level) & Adenovirus vector & 0.002 & 0.064 & 0.97 & $>0.99$ & $>0.99$ \\
\hline & Time since second vaccination (weeks) & Adenovirus vector & -0.010 & 0.010 & 0.33 & $>0.99$ & $>0.99$ \\
\hline \multirow{8}{*}{$\begin{array}{l}\text { Age group (18 to } 29 \\
\text { years) }\end{array}$} & Second vaccination (change in level) & 30 to 39 years & 0.182 & 0.145 & 0.21 & $>0.99$ & $>0.99$ \\
\hline & & 40 to 49 years & 0.206 & 0.136 & 0.13 & $>0.99$ & $>0.99$ \\
\hline & & 50 to 59 years & 0.239 & 0.134 & 0.07 & $>0.99$ & $>0.99$ \\
\hline & & 60 to 70 years & 0.177 & 0.137 & 0.19 & $>0.99$ & $>0.99$ \\
\hline & Time since second vaccination (weeks) & 30 to 39 years & 0.041 & 0.026 & 0.12 & $>0.99$ & $>0.99$ \\
\hline & & 40 to 49 years & 0.037 & 0.025 & 0.15 & $>0.99$ & $>0.99$ \\
\hline & & 50 to 59 years & 0.035 & 0.025 & 0.17 & $>0.99$ & $>0.99$ \\
\hline & & 60 to 70 years & 0.033 & 0.026 & 0.20 & $>0.99$ & $>0.99$ \\
\hline \multirow{2}{*}{ Sex (male) } & Second vaccination (change in level) & Female & -0.124 & 0.064 & 0.06 & $>0.99$ & $>0.99$ \\
\hline & Time since second vaccination (weeks) & Female & -0.015 & 0.011 & 0.16 & $>0.99$ & $>0.99$ \\
\hline \multirow[t]{2}{*}{ Ethnic group (white) } & Second vaccination (change in level) & Non-white & -0.092 & 0.112 & 0.41 & $>0.99$ & $>0.99$ \\
\hline & Time since second vaccination (weeks) & Non-white & -0.004 & 0.018 & 0.81 & $>0.99$ & $>0.99$ \\
\hline \multirow{8}{*}{$\begin{array}{l}\text { Area deprivation quintile } \\
\text { group }(1, \text { most deprived })\end{array}$} & Second vaccination (change in level) & 2 & 0.123 & 0.108 & 0.26 & $>0.99$ & $>0.99$ \\
\hline & & 3 & 0.026 & 0.105 & 0.81 & $>0.99$ & $>0.99$ \\
\hline & & 4 & 0.041 & 0.103 & 0.69 & $>0.99$ & $>0.99$ \\
\hline & & 5 (least deprived) & 0.242 & 0.104 & 0.02 & $>0.99$ & $>0.99$ \\
\hline & Time since second vaccination (weeks) & 2 & 0.001 & 0.017 & 0.94 & $>0.99$ & $>0.99$ \\
\hline & & 3 & -0.026 & 0.016 & 0.09 & $>0.99$ & $>0.99$ \\
\hline & & 4 & -0.015 & 0.015 & 0.34 & $>0.99$ & $>0.99$ \\
\hline & & 5 (least deprived) & 0.017 & 0.016 & 0.30 & $>0.99$ & $>0.99$ \\
\hline \multirow[t]{2}{*}{ Health conditions (No) } & Second vaccination (change in level) & Yes & -0.049 & 0.071 & 0.49 & $>0.99$ & $>0.99$ \\
\hline & Time since second vaccination (weeks) & Yes & 0.004 & 0.010 & 0.67 & $>0.99$ & $>0.99$ \\
\hline \multirow{2}{*}{$\begin{array}{l}\text { Hospitalised at acute } \\
\text { phase of infection (No) }\end{array}$} & Second vaccination (change in level) & Yes & 0.076 & 0.113 & 0.50 & $>0.99$ & $>0.99$ \\
\hline & Time since second vaccination (weeks) & Yes & -0.005 & 0.017 & 0.79 & $>0.99$ & $>0.99$ \\
\hline \multirow{4}{*}{$\begin{array}{l}\text { Days from infection to } \\
\text { vaccination (restricted } \\
\text { cubic spline) }\end{array}$} & Second vaccination (change in level) & First term & -0.107 & 0.142 & 0.45 & $>0.99$ & $>0.99$ \\
\hline & & Second term & -0.025 & 0.085 & 0.77 & $>0.99$ & $>0.99$ \\
\hline & Time since second vaccination (weeks) & First term & -0.057 & 0.025 & 0.02 & $>0.99$ & $>0.99$ \\
\hline & & Second term & -0.005 & 0.014 & 0.72 & $>0.99$ & $>0.99$ \\
\hline
\end{tabular}

Notes: B-Y: Benjamini-Yekutieli; H-B: Holm-Bonferroni; mRNA: messenger ribonucleic acid; SE: standard error. 
Supplementary Table 5c. Interactions between vaccination and personal characteristics: activity-limiting Long Covid, first vaccination

\begin{tabular}{|c|c|c|c|c|c|c|c|}
\hline Modifier (comparator) & Exposure & Group & Estimate & SE & P-value & H-B p-value & B-Y p-value \\
\hline \multirow{2}{*}{$\begin{array}{l}\text { Vaccine type (mRNA } \\
\text { vaccine) }\end{array}$} & First vaccination (change in level) & Adenovirus vector & 0.045 & 0.087 & 0.60 & $>0.99$ & $>0.99$ \\
\hline & Time since first vaccination (weeks) & Adenovirus vector & 0.004 & 0.012 & 0.75 & $>0.99$ & $>0.99$ \\
\hline \multirow{8}{*}{$\begin{array}{l}\text { Age group (18 to } 29 \\
\text { years) }\end{array}$} & First vaccination (change in level) & 30 to 39 years & 0.267 & 0.199 & 0.18 & $>0.99$ & $>0.99$ \\
\hline & & 40 to 49 years & 0.306 & 0.195 & 0.12 & $>0.99$ & $>0.99$ \\
\hline & & 50 to 59 years & 0.273 & 0.195 & 0.16 & $>0.99$ & $>0.99$ \\
\hline & & 60 to 70 years & 0.203 & 0.206 & 0.33 & $>0.99$ & $>0.99$ \\
\hline & Time since first vaccination (weeks) & 30 to 39 years & -0.029 & 0.032 & 0.36 & $>0.99$ & $>0.99$ \\
\hline & & 40 to 49 years & -0.024 & 0.031 & 0.45 & $>0.99$ & $>0.99$ \\
\hline & & 50 to 59 years & -0.025 & 0.031 & 0.42 & $>0.99$ & $>0.99$ \\
\hline & & 60 to 70 years & -0.023 & 0.031 & 0.45 & $>0.99$ & $>0.99$ \\
\hline \multirow{2}{*}{ Sex (male) } & First vaccination (change in level) & Female & -0.123 & 0.086 & 0.15 & $>0.99$ & $>0.99$ \\
\hline & Time since first vaccination (weeks) & Female & 0.023 & 0.011 & 0.04 & $>0.99$ & $>0.99$ \\
\hline \multirow[t]{2}{*}{ Ethnic group (white) } & First vaccination (change in level) & Non-white & -0.030 & 0.154 & 0.85 & $>0.99$ & $>0.99$ \\
\hline & Time since first vaccination (weeks) & Non-white & 0.019 & 0.019 & 0.34 & $>0.99$ & $>0.99$ \\
\hline \multirow{8}{*}{$\begin{array}{l}\text { Area deprivation quintile } \\
\text { group }(1, \text { most deprived) }\end{array}$} & First vaccination (change in level) & 2 & 0.385 & 0.141 & 0.006 & 0.35 & 0.56 \\
\hline & & 3 & 0.045 & 0.133 & 0.74 & $>0.99$ & $>0.99$ \\
\hline & & 4 & 0.138 & 0.132 & 0.30 & $>0.99$ & $>0.99$ \\
\hline & & 5 (least deprived) & 0.135 & 0.135 & 0.32 & $>0.99$ & $>0.99$ \\
\hline & Time since first vaccination (weeks) & 2 & -0.028 & 0.018 & 0.11 & $>0.99$ & $>0.99$ \\
\hline & & 3 & 0.008 & 0.016 & 0.62 & $>0.99$ & $>0.99$ \\
\hline & & 4 & -0.015 & 0.016 & 0.36 & $>0.99$ & $>0.99$ \\
\hline & & 5 (least deprived) & -0.022 & 0.017 & 0.20 & $>0.99$ & $>0.99$ \\
\hline \multirow[t]{2}{*}{ Health conditions (No) } & First vaccination (change in level) & Yes & -0.030 & 0.092 & 0.75 & $>0.99$ & $>0.99$ \\
\hline & Time since first vaccination (weeks) & Yes & -0.001 & 0.010 & 0.91 & $>0.99$ & $>0.99$ \\
\hline \multirow{2}{*}{$\begin{array}{l}\text { Hospitalised at acute } \\
\text { phase of infection (No) }\end{array}$} & First vaccination (change in level) & Yes & 0.135 & 0.155 & 0.38 & $>0.99$ & $>0.99$ \\
\hline & Time since first vaccination (weeks) & Yes & -0.015 & 0.017 & 0.38 & $>0.99$ & $>0.99$ \\
\hline \multirow{4}{*}{$\begin{array}{l}\text { Days from infection to } \\
\text { vaccination (restricted } \\
\text { cubic spline) }\end{array}$} & First vaccination (change in level) & First term & -0.606 & 0.374 & 0.11 & $>0.99$ & $>0.99$ \\
\hline & & Second term & -0.031 & 0.111 & 0.78 & $>0.99$ & $>0.99$ \\
\hline & Time since first vaccination (weeks) & First term & 0.078 & 0.028 & 0.005 & 0.30 & 0.56 \\
\hline & & Second term & 0.027 & 0.013 & 0.04 & $>0.99$ & $>0.99$ \\
\hline
\end{tabular}

Notes: B-Y: Benjamini-Yekutieli; H-B: Holm-Bonferroni; mRNA: messenger ribonucleic acid; SE: standard error. 
Supplementary Table $\mathbf{5 d}$. Interactions between vaccination and personal characteristics: activity-limiting Long Covid, second vaccination

\begin{tabular}{|c|c|c|c|c|c|c|c|}
\hline Modifier (comparator) & Exposure & Group & Estimate & SE & P-value & H-B p-value & B-Y p-value \\
\hline \multirow{2}{*}{$\begin{array}{l}\text { Vaccine type (mRNA } \\
\text { vaccine) }\end{array}$} & Second vaccination (change in level) & Adenovirus vector & -0.116 & 0.080 & 0.15 & $>0.99$ & $>0.99$ \\
\hline & Time since second vaccination (weeks) & Adenovirus vector & 0.004 & 0.013 & 0.73 & $>0.99$ & $>0.99$ \\
\hline \multirow{8}{*}{$\begin{array}{l}\text { Age group (18 to } 29 \\
\text { years) }\end{array}$} & Second vaccination (change in level) & 30 to 39 years & 0.112 & 0.198 & 0.57 & $>0.99$ & $>0.99$ \\
\hline & & 40 to 49 years & 0.051 & 0.187 & 0.79 & $>0.99$ & $>0.99$ \\
\hline & & 50 to 59 years & 0.104 & 0.183 & 0.57 & $>0.99$ & $>0.99$ \\
\hline & & 60 to 70 years & 0.065 & 0.185 & 0.73 & $>0.99$ & $>0.99$ \\
\hline & Time since second vaccination (weeks) & 30 to 39 years & 0.045 & 0.041 & 0.28 & $>0.99$ & $>0.99$ \\
\hline & & 40 to 49 years & 0.035 & 0.040 & 0.38 & $>0.99$ & $>0.99$ \\
\hline & & 50 to 59 years & 0.029 & 0.040 & 0.47 & $>0.99$ & $>0.99$ \\
\hline & & 60 to 70 years & 0.027 & 0.040 & 0.50 & $>0.99$ & $>0.99$ \\
\hline \multirow{2}{*}{ Sex (male) } & Second vaccination (change in level) & Female & -0.141 & 0.080 & 0.08 & $>0.99$ & $>0.99$ \\
\hline & Time since second vaccination (weeks) & Female & -0.025 & 0.013 & 0.047 & $>0.99$ & $>0.99$ \\
\hline \multirow[t]{2}{*}{ Ethnic group (white) } & Second vaccination (change in level) & Non-white & -0.169 & 0.138 & 0.22 & $>0.99$ & $>0.99$ \\
\hline & Time since second vaccination (weeks) & Non-white & -0.011 & 0.021 & 0.61 & $>0.99$ & $>0.99$ \\
\hline \multirow{8}{*}{$\begin{array}{l}\text { Area deprivation quintile } \\
\text { group }(1, \text { most deprived) }\end{array}$} & Second vaccination (change in level) & 2 & 0.190 & 0.129 & 0.14 & $>0.99$ & $>0.99$ \\
\hline & & 3 & -0.046 & 0.125 & 0.71 & $>0.99$ & $>0.99$ \\
\hline & & 4 & 0.107 & 0.124 & 0.39 & $>0.99$ & $>0.99$ \\
\hline & & 5 (least deprived) & 0.247 & 0.125 & 0.048 & $>0.99$ & $>0.99$ \\
\hline & Time since second vaccination (weeks) & 2 & 0.017 & 0.020 & 0.40 & $>0.99$ & $>0.99$ \\
\hline & & 3 & -0.022 & 0.018 & 0.22 & $>0.99$ & $>0.99$ \\
\hline & & 4 & 0.004 & 0.018 & 0.82 & $>0.99$ & $>0.99$ \\
\hline & & 5 (least deprived) & 0.010 & 0.019 & 0.60 & $>0.99$ & $>0.99$ \\
\hline \multirow[t]{2}{*}{ Health conditions (No) } & Second vaccination (change in level) & Yes & 0.031 & 0.080 & 0.70 & $>0.99$ & $>0.99$ \\
\hline & Time since second vaccination (weeks) & Yes & 0.008 & 0.011 & 0.48 & $>0.99$ & $>0.99$ \\
\hline \multirow{2}{*}{$\begin{array}{l}\text { Hospitalised at acute } \\
\text { phase of infection (No) }\end{array}$} & Second vaccination (change in level) & Yes & 0.087 & 0.124 & 0.48 & $>0.99$ & $>0.99$ \\
\hline & Time since second vaccination (weeks) & Yes & 0.014 & 0.019 & 0.45 & $>0.99$ & $>0.99$ \\
\hline \multirow{4}{*}{$\begin{array}{l}\text { Days from infection to } \\
\text { vaccination (restricted } \\
\text { cubic spline) }\end{array}$} & Second vaccination (change in level) & First term & -0.074 & 0.174 & 0.67 & $>0.99$ & $>0.99$ \\
\hline & & Second term & -0.080 & 0.105 & 0.44 & $>0.99$ & $>0.99$ \\
\hline & Time since second vaccination (weeks) & First term & -0.089 & 0.029 & 0.002 & 0.12 & 0.56 \\
\hline & & Second term & -0.015 & 0.017 & 0.35 & $>0.99$ & $>0.99$ \\
\hline
\end{tabular}

Notes: B-Y: Benjamini-Yekutieli; H-B: Holm-Bonferroni; mRNA: messenger ribonucleic acid; SE: standard error. 
Supplementary Table 6. Logistic regression model output for time trends in individual Long Covid symptoms and vaccination exposure variables

\begin{tabular}{|c|c|c|c|c|c|}
\hline Outcome & Variable & Estimate & SE & P-value & Odds ratio $(95 \% \mathrm{Cl})$ \\
\hline \multirow{5}{*}{$\begin{array}{l}\text { Difficulty } \\
\text { concentrating }\end{array}$} & Time trajectory (per week) & 0.010 & 0.005 & 0.051 & $1.010(1.000$ to 1.020$)$ \\
\hline & First vaccination (change in level) & -0.049 & 0.061 & 0.42 & $0.953(0.846$ to 1.073$)$ \\
\hline & Second vaccination (change in level) & -0.047 & 0.050 & 0.35 & 0.954 (0.866 to 1.052$)$ \\
\hline & Time since first vaccination (per week) & -0.002 & 0.008 & 0.81 & $0.998(0.983$ to 1.014$)$ \\
\hline & Time since second vaccination (per week) & -0.008 & 0.008 & 0.29 & $0.992(0.977$ to 1.007$)$ \\
\hline \multirow[t]{5}{*}{ Fatigue } & Time trajectory (per week) & 0.001 & 0.004 & 0.77 & $1.001(0.994$ to 1.009$)$ \\
\hline & First vaccination (change in level) & -0.072 & 0.046 & 0.12 & $0.930(0.849$ to 1.019$)$ \\
\hline & Second vaccination (change in level) & -0.102 & 0.040 & 0.01 & $0.903(0.835$ to 0.976$)$ \\
\hline & Time since first vaccination (per week) & 0.006 & 0.007 & 0.39 & $1.006(0.993$ to 1.019$)$ \\
\hline & Time since second vaccination (per week) & -0.011 & 0.006 & 0.08 & $0.989(0.977$ to 1.001$)$ \\
\hline \multirow[t]{5}{*}{ Headache } & Time trajectory (per week) & -0.004 & 0.005 & 0.46 & $0.996(0.987$ to 1.006$)$ \\
\hline & First vaccination (change in level) & -0.089 & 0.062 & 0.15 & 0.914 (0.810 to 1.033$)$ \\
\hline & Second vaccination (change in level) & -0.094 & 0.053 & 0.08 & $0.910(0.819$ to 1.010$)$ \\
\hline & Time since first vaccination (per week) & 0.010 & 0.008 & 0.21 & $1.011(0.994$ to 1.027$)$ \\
\hline & Time since second vaccination (per week) & -0.020 & 0.008 & 0.02 & $0.980(0.964$ to 0.996$)$ \\
\hline \multirow[t]{5}{*}{ Loss of smell } & Time trajectory (per week) & 0.002 & 0.005 & 0.73 & $1.002(0.993$ to 1.011$)$ \\
\hline & First vaccination (change in level) & -0.134 & 0.055 & 0.02 & 0.875 (0.785 to 0.975$)$ \\
\hline & Second vaccination (change in level) & -0.091 & 0.049 & 0.06 & $0.913(0.829$ to 1.005$)$ \\
\hline & Time since first vaccination (per week) & 0.009 & 0.008 & 0.22 & $1.009(0.994$ to 1.025$)$ \\
\hline & Time since second vaccination (per week) & -0.016 & 0.008 & 0.04 & 0.984 (0.969 to 0.999$)$ \\
\hline \multirow[t]{5}{*}{ Loss of taste } & Time trajectory (per week) & -0.005 & 0.005 & 0.32 & $0.995(0.985$ to 1.005$)$ \\
\hline & First vaccination (change in level) & -0.097 & 0.063 & 0.13 & $0.908(0.802$ to 1.027$)$ \\
\hline & Second vaccination (change in level) & -0.094 & 0.052 & 0.07 & $0.910(0.821$ to 1.008$)$ \\
\hline & Time since first vaccination (per week) & 0.018 & 0.008 & 0.03 & $1.019(1.002$ to 1.036$)$ \\
\hline & Time since second vaccination (per week) & -0.019 & 0.008 & 0.02 & $0.981(0.965$ to 0.997$)$ \\
\hline \multirow{5}{*}{$\begin{array}{l}\text { Memory loss or } \\
\text { confusion }\end{array}$} & Time trajectory (per week) & 0.014 & 0.006 & 0.01 & $1.014(1.003$ to 1.025$)$ \\
\hline & First vaccination (change in level) & -0.026 & 0.070 & 0.71 & $0.974(0.850$ to 1.117$)$ \\
\hline & Second vaccination (change in level) & 0.029 & 0.055 & 0.60 & $1.029(0.924$ to 1.147$)$ \\
\hline & Time since first vaccination (per week) & -0.007 & 0.009 & 0.41 & $0.993(0.976$ to 1.010$)$ \\
\hline & Time since second vaccination (per week) & -0.009 & 0.009 & 0.31 & $0.991(0.975$ to 1.008$)$ \\
\hline \multirow[t]{5}{*}{ Muscle ache } & Time trajectory (per week) & 0.006 & 0.005 & 0.23 & $1.006(0.996$ to 1.016$)$ \\
\hline & First vaccination (change in level) & -0.009 & 0.062 & 0.88 & $0.991(0.878$ to 1.118$)$ \\
\hline & Second vaccination (change in level) & -0.054 & 0.049 & 0.28 & $0.948(0.860$ to 1.044$)$ \\
\hline & Time since first vaccination (per week) & -0.001 & 0.008 & 0.88 & $0.999(0.983$ to 1.015$)$ \\
\hline & Time since second vaccination (per week) & -0.009 & 0.008 & 0.27 & 0.991 (0.976 to 1.007$)$ \\
\hline
\end{tabular}




\begin{tabular}{|c|c|c|c|c|c|}
\hline \multirow[t]{5}{*}{ Shortness of breath } & Time trajectory (per week) & -0.001 & 0.005 & 0.90 & $0.999(0.991$ to 1.008$)$ \\
\hline & First vaccination (change in level) & -0.055 & 0.054 & 0.31 & $0.946(0.851$ to 1.052$)$ \\
\hline & Second vaccination (change in level) & 0.012 & 0.048 & 0.81 & $1.012(0.921$ to 1.111$)$ \\
\hline & Time since first vaccination (per week) & -0.005 & 0.008 & 0.50 & $0.995(0.979$ to 1.010$)$ \\
\hline & Time since second vaccination (per week) & -0.002 & 0.008 & 0.76 & $0.998(0.983$ to 1.013$)$ \\
\hline \multirow[t]{5}{*}{ Trouble sleeping } & Time trajectory (per week) & 0.000 & 0.005 & 0.95 & $1.000(0.990$ to 1.010$)$ \\
\hline & First vaccination (change in level) & -0.092 & 0.063 & 0.15 & $0.912(0.806$ to 1.033$)$ \\
\hline & Second vaccination (change in level) & -0.094 & 0.054 & 0.08 & 0.910 (0.818 to 1.012$)$ \\
\hline & Time since first vaccination (per week) & 0.004 & 0.009 & 0.67 & $1.004(0.987$ to 1.021$)$ \\
\hline & Time since second vaccination (per week) & -0.003 & 0.008 & 0.69 & $0.997(0.980$ to 1.013$)$ \\
\hline \multirow[t]{5}{*}{ Worry or anxiety } & Time trajectory (per week) & 0.008 & 0.005 & 0.15 & $1.008(0.997$ to 1.018$)$ \\
\hline & First vaccination (change in level) & -0.090 & 0.067 & 0.18 & $0.914(0.802$ to 1.042$)$ \\
\hline & Second vaccination (change in level) & -0.034 & 0.057 & 0.55 & $0.967(0.865$ to 1.080$)$ \\
\hline & Time since first vaccination (per week) & 0.000 & 0.009 & 0.98 & $1.000(0.983$ to 1.018$)$ \\
\hline & Time since second vaccination (per week) & -0.010 & 0.009 & 0.27 & $0.990(0.973$ to 1.008$)$ \\
\hline \multirow{5}{*}{$\begin{array}{l}\text { At least } 3 \text { of } 21 \\
\text { symptoms }\end{array}$} & Time trajectory (per week) & 0.005 & 0.004 & 0.21 & $1.005(0.997$ to 1.014$)$ \\
\hline & First vaccination (change in level) & -0.067 & 0.052 & 0.20 & 0.935 (0.844 to 1.037$)$ \\
\hline & Second vaccination (change in level) & -0.072 & 0.045 & 0.11 & $0.931(0.852$ to 1.016$)$ \\
\hline & Time since first vaccination (per week) & -0.001 & 0.007 & 0.94 & $0.999(0.985$ to 1.014$)$ \\
\hline & Time since second vaccination (per week) & -0.008 & 0.007 & 0.25 & $0.992(0.978$ to 1.006$)$ \\
\hline \multirow{5}{*}{$\begin{array}{l}\text { At least } 5 \text { of } 21 \\
\text { symptoms }\end{array}$} & Time trajectory (per week) & 0.005 & 0.005 & 0.36 & $1.005(0.995$ to 1.015$)$ \\
\hline & First vaccination (change in level) & -0.039 & 0.063 & 0.54 & $0.962(0.850$ to 1.089$)$ \\
\hline & Second vaccination (change in level) & -0.018 & 0.052 & 0.73 & $0.982(0.886$ to 1.088$)$ \\
\hline & Time since first vaccination (per week) & -0.005 & 0.009 & 0.56 & 0.995 (0.979 to 1.012$)$ \\
\hline & Time since second vaccination (per week) & -0.004 & 0.008 & 0.62 & $0.996(0.979$ to 1.012$)$ \\
\hline
\end{tabular}

Notes: Cl: confidence interval; SE: standard error. Estimates and standard errors are on the logit scale. Odds ratios for 'time since first/second vaccination' represent modification of the time trajectory. Estimates and odds ratios are adjusted for age, sex, white or non-white ethnicity, region/country, area deprivation quintile group, health status, whether a patient-facing health or social care worker, whether hospitalised with acute COVID-19, and calendar time of infection. 
medRxiv preprint doi: https://doi.org/10.1101/2021.12.09.21267516; this version posted December 9, 2021. The copyright holder for this preprint (which was not certified by peer review) is the author/funder, who has granted medRxiv a license to display the preprint in

It is made available under a CC-BY 4.0 International license .

Supplementary Figure 1. Study participant flow diagram

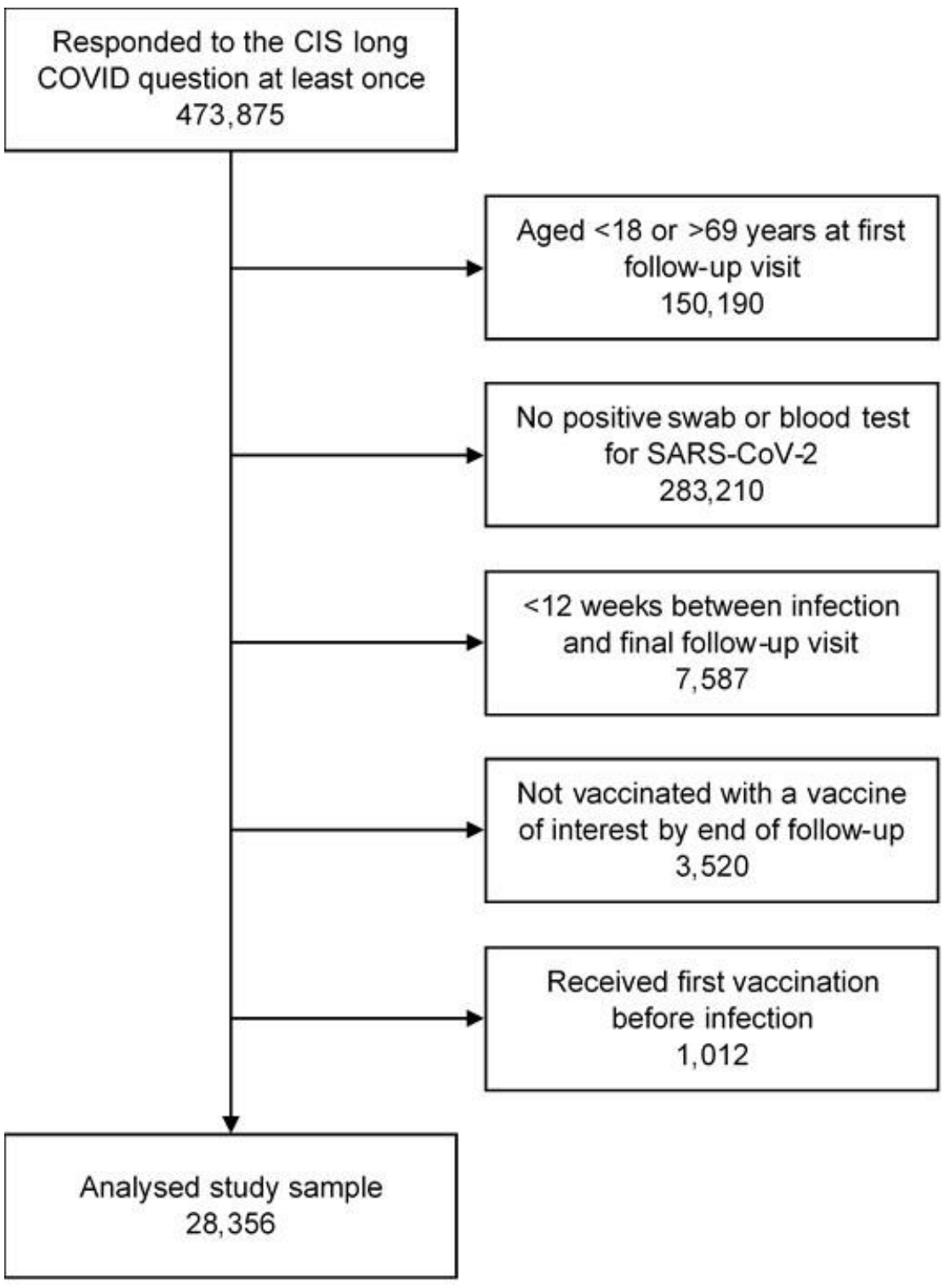


medRxiv preprint doi: https://doi.org/10.1101/2021.12.09.21267516; this version posted December $9,2021$. The copyright holder for this preprint (which was not certified by peer review) is the author/funder, who has granted medRxiv a license to display the preprint in perpetuity.

It is made available under a CC-BY 4.0 International license.

Supplementary Figure 2a. Modelled probabilities of Long Covid for a hypothetical study participant, sensitivity analysis 1: participants with at least one observation before and after their first vaccination

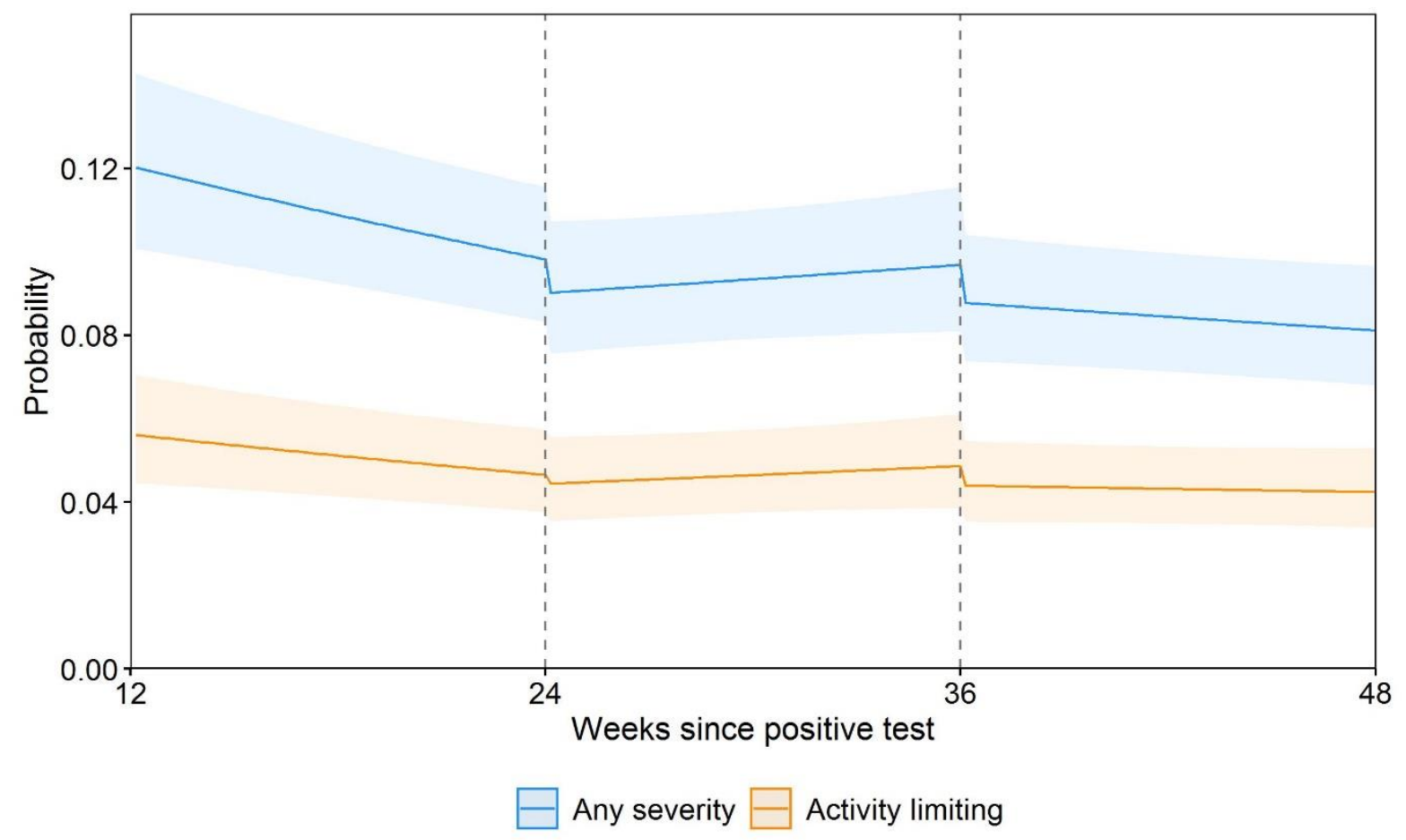

Notes: The sample comprised 12,971 participants with a mean age of 42 years and $10.8 \%$ with underlying health conditions (two of the main determinants of vaccination timing). Probabilities are shown for a participant aged 50 years and in the modal group for other covariates (female, white, living in London, in an area in the least deprived quintile group, not a patient-facing health or social care worker, no pre-existing health conditions, not hospitalised at the acute phase of infection, and infected on 7 September 2020). While the estimated probabilities are specific to this profile, the proportional changes in probabilities after vaccination do not vary across characteristics and can therefore be generalised to other profiles. Dashed lines indicate the timing of vaccination. Shaded areas are $95 \%$ confidence intervals. 
medRxiv preprint doi: https://doi.org/10.1101/2021.12.09.21267516; this version posted December $9,2021$. The copyright holder for this preprint (which was not certified by peer review) is the author/funder, who has granted medRxiv a license to display the preprint in perpetuity.

It is made available under a CC-BY 4.0 International license.

Supplementary Figure 2b. Modelled probabilities of Long Covid for a hypothetical study participant, sensitivity analysis 2: participants with at least one observation before and after their second vaccination

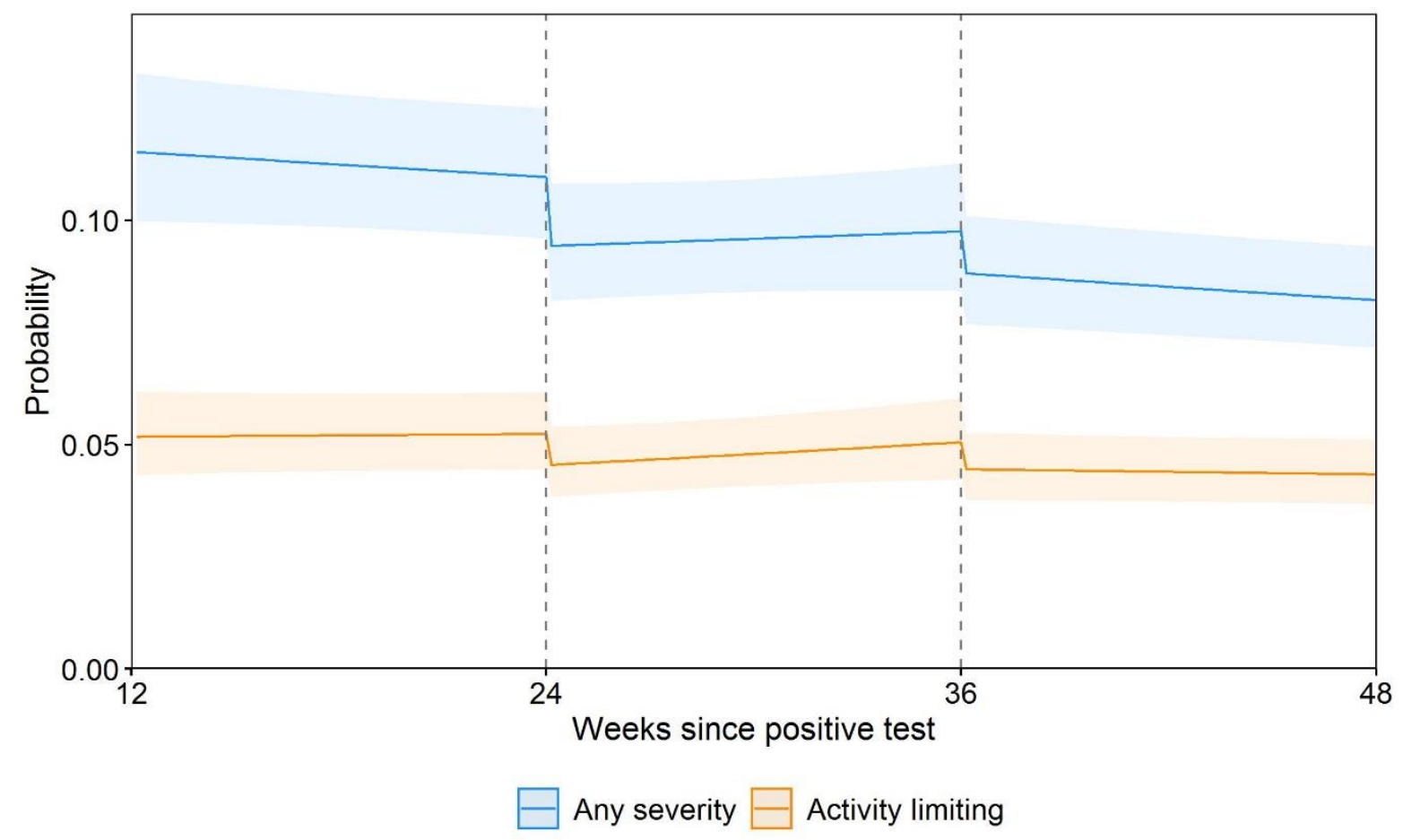

Notes: The sample comprises 20,335 participants with a mean age of 48 years and $14.0 \%$ with underlying health conditions (two of the main determinants of vaccination timing). Probabilities are shown for a participant aged 50 years and in the modal group for other covariates (female, white, living in London, in an area in the least deprived quintile group, not a patient-facing health or social care worker, no pre-existing health conditions, not hospitalised at the acute phase of infection, and infected on 7 September 2020). While the estimated probabilities are specific to this profile, the proportional changes in probabilities after vaccination do not vary across characteristics and can therefore be generalised to other profiles. Dashed lines indicate the timing of vaccination. Shaded areas are $95 \%$ confidence intervals. 
medRxiv preprint doi: https://doi.org/10.1101/2021.12.09.21267516; this version posted December 9, 2021. The copyright holder for this preprint (which was not certified by peer review) is the author/funder, who has granted medRxiv a license to display the preprint in perpetuity.

It is made available under a CC-BY 4.0 International license.

Supplementary Figure 2c. Modelled probabilities of Long Covid for a hypothetical study participant, sensitivity analysis 3: participants with at least three observations after their first vaccination

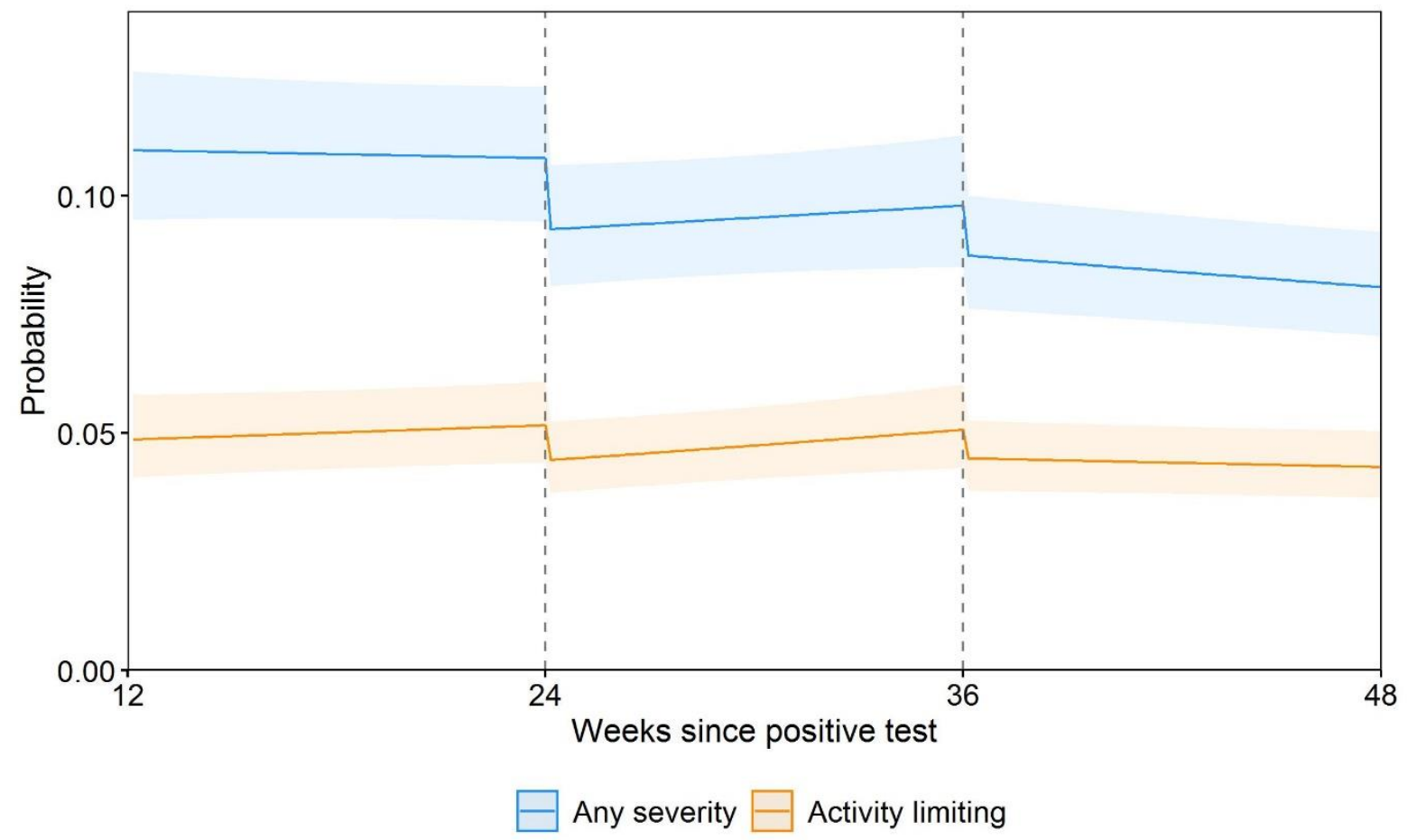

Notes: The sample comprises 20,635 participants with a mean age of 49 years and $15.1 \%$ with underlying health conditions (two of the main determinants of vaccination timing). Probabilities are shown for a participant aged 50 years and in the modal group for other covariates (female, white, living in London, in an area in the least deprived quintile group, not a patient-facing health or social care worker, no pre-existing health conditions, not hospitalised at the acute phase of infection, and infected on 7 September 2020). While the estimated probabilities are specific to this profile, the proportional changes in probabilities after vaccination do not vary across characteristics and can therefore be generalised to other profiles. Dashed lines indicate the timing of vaccination. Shaded areas are $95 \%$ confidence intervals. 
medRxiv preprint doi: https://doi.org/10.1101/2021.12.09.21267516; this version posted December 9, 2021. The copyright holder for this preprint (which was not certified by peer review) is the author/funder, who has granted medRxiv a license to display the preprint in perpetuity.

It is made available under a CC-BY 4.0 International license .

Supplementary Figure 2d. Modelled probabilities of Long Covid for a hypothetical study participant, sensitivity analysis 4: participants with at least three observations after their second vaccination

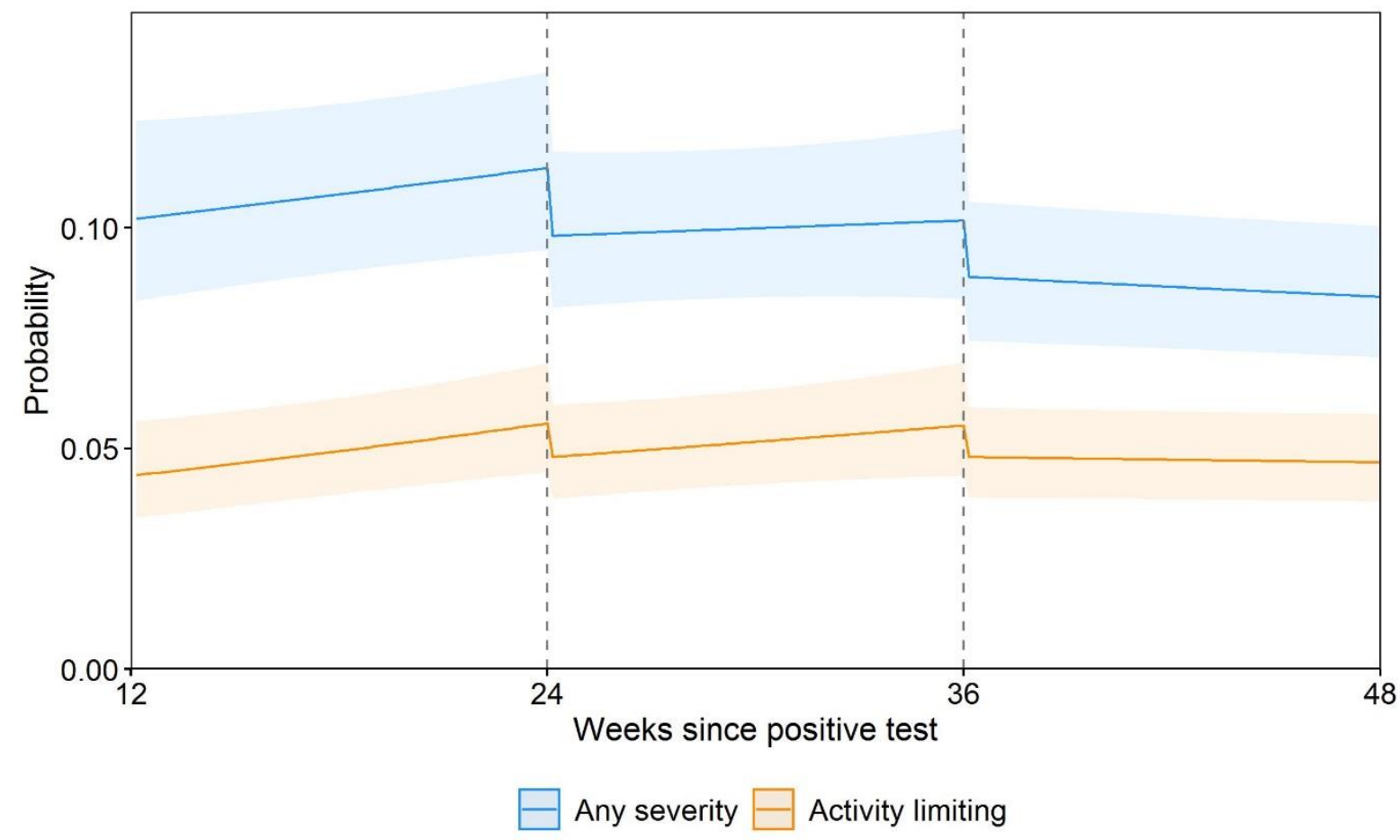

Notes: The sample comprises 12,288 participants with a mean age of 52 years and $18.0 \%$ with underlying health conditions (two of the main determinants of vaccination timing). Probabilities are shown for a participant aged 50 years and in the modal group for other covariates (female, white, living in London, in an area in the least deprived quintile group, not a patient-facing health or social care worker, no pre-existing health conditions, not hospitalised at the acute phase of infection, and infected on 7 September 2020). While the estimated probabilities are specific to this profile, the proportional changes in probabilities after vaccination do not vary across characteristics and can therefore be generalised to other profiles. Dashed lines indicate the timing of vaccination. Shaded areas are $95 \%$ confidence intervals. 
medRxiv preprint doi: https://doi.org/10.1101/2021.12.09.21267516; this version posted December 9, 2021. The copyright holder for this preprint (which was not certified by peer review) is the author/funder, who has granted medRxiv a license to display the preprint in

perpetuity.
It is made available under a CC-BY 4.0 International license .

Supplementary Figure 2e. Modelled probabilities of Long Covid for a hypothetical study participant, sensitivity analysis 5: omitting follow-up visits within the first week after each vaccination

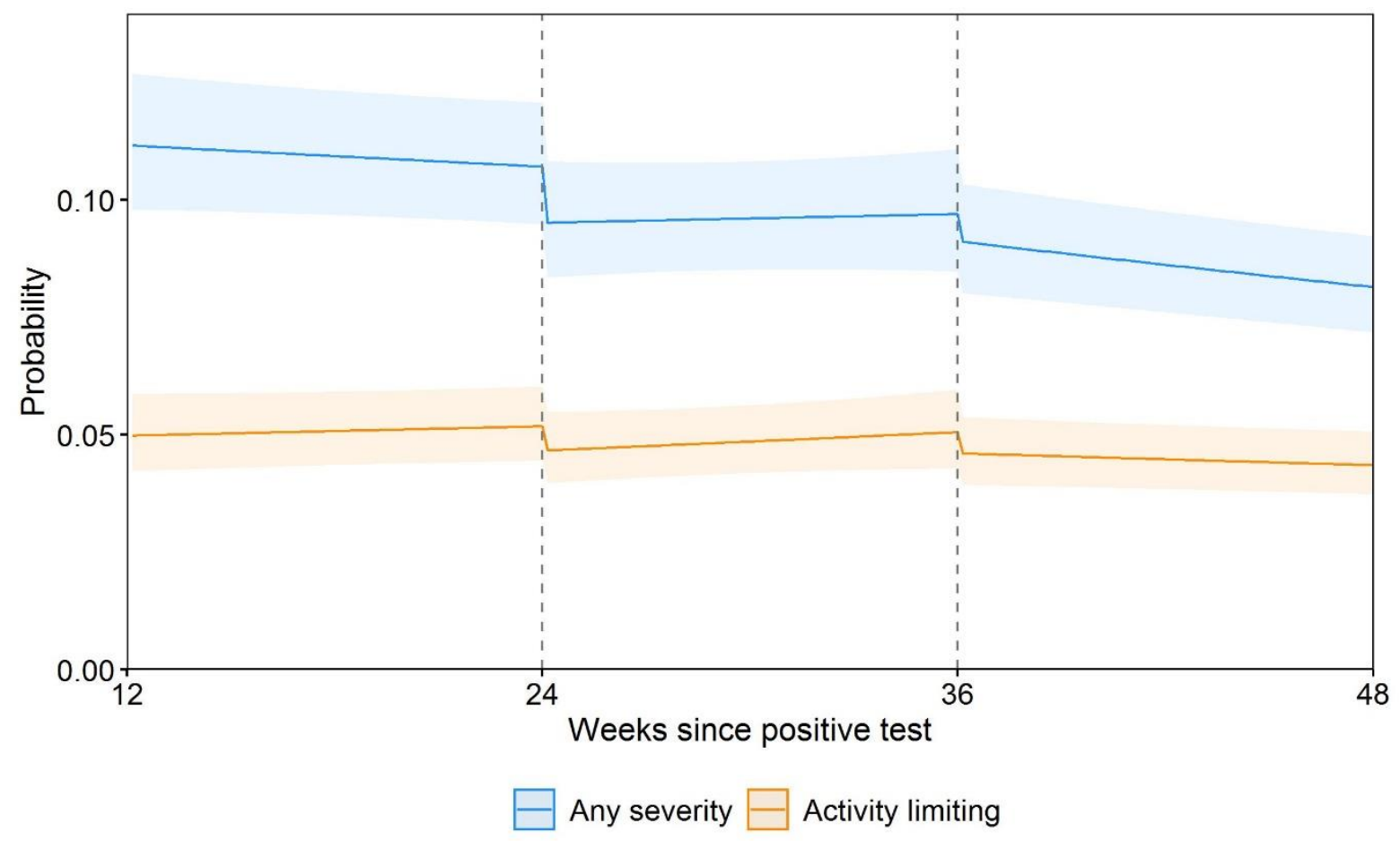

Notes: This analysis was based on 120,077 (89.6\%) of the 133,965 follow-up visits used in the main analysis. Probabilities are shown for a participant aged 50 years and in the modal group for other covariates (female, white, living in London, in an area in the least deprived quintile group, not a patient-facing health or social care worker, no pre-existing health conditions, not hospitalised at the acute phase of infection, and infected on 7 September 2020). While the estimated probabilities are specific to this profile, the proportional changes in probabilities after vaccination do not vary across characteristics and can therefore be generalised to other profiles. Dashed lines indicate the timing of vaccination. Shaded areas are $95 \%$ confidence intervals. 
medRxiv preprint doi: https://doi.org/10.1101/2021.12.09.21267516; this version posted December 9, 2021. The copyright holder for this preprint (which was not certified by peer review) is the author/funder, who has granted medRxiv a license to display the preprint in

perpetuity.
It is made available under a CC-BY 4.0 International license.

Supplementary Figure 2f. Modelled probabilities of Long Covid for a hypothetical study participant, sensitivity analysis 6 : including participants who remained unvaccinated by their last follow-up visit during the study period

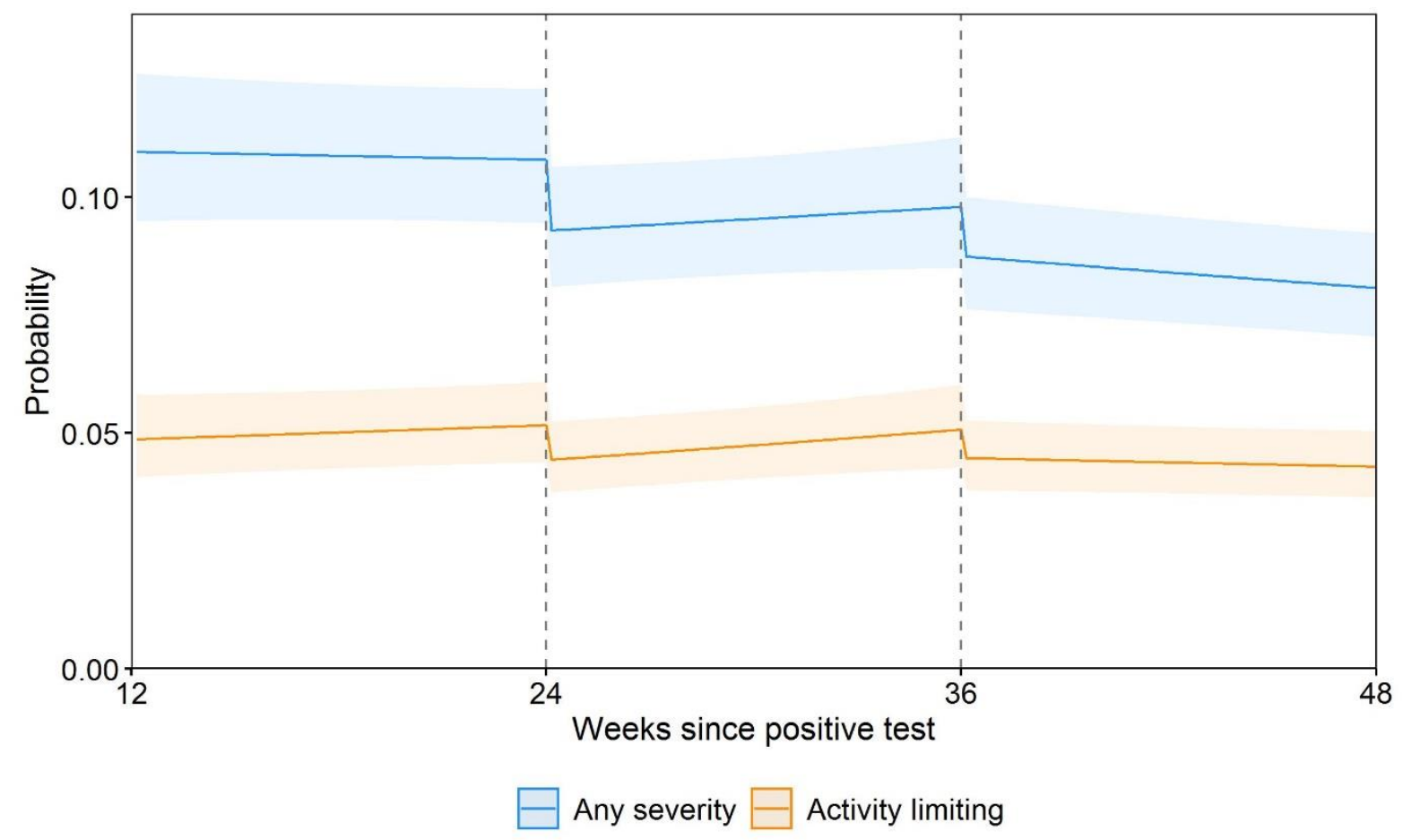

Notes: This analysis was based on 31,663 participants (compared with 28,356 in the main analysis). Probabilities are shown for a participant aged 50 years and in the modal group for other covariates (female, white, living in London, in an area in the least deprived quintile group, not a patient-facing health or social care worker, no pre-existing health conditions, not hospitalised at the acute phase of infection, and infected on 7 September 2020). While the estimated probabilities are specific to this profile, the proportional changes in probabilities after vaccination do not vary across characteristics and can therefore be generalised to other profiles. Dashed lines indicate the timing of vaccination. Shaded areas are $95 \%$ confidence intervals. 
medRxiv preprint doi: https://doi.org/10.1101/2021.12.09.21267516; this version posted December 9, 2021. The copyright holder for this preprint (which was not certified by peer review) is the author/funder, who has granted medRxiv a license to display the preprint in

perpetuity.
It is made available under a CC-BY 4.0 International license .

Supplementary Figure 2g. Modelled probabilities of Long Covid for a hypothetical study participant, sensitivity analysis 7: excluding participants infected in the first wave of the pandemic

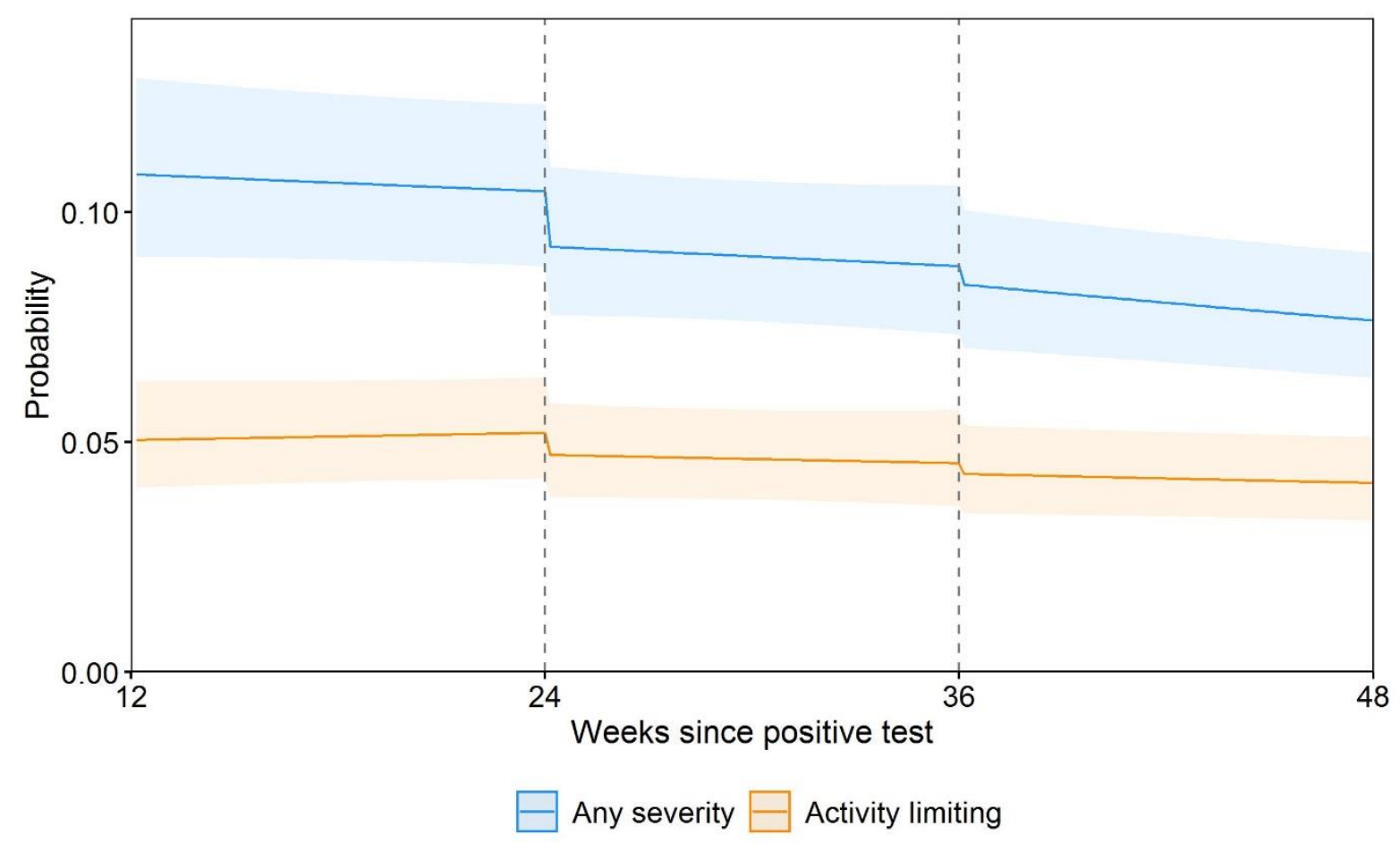

Notes: This analysis was based on 19,085 participants (compared with 28,356 in the main analysis) infected from 11 September 2020 onwards. Probabilities are shown for a participant aged 50 years and in the modal group for other covariates (female, white, living in London, in an area in the least deprived quintile group, not a patient-facing health or social care worker, no pre-existing health conditions, not hospitalised at the acute phase of infection, and infected on 7 September 2020). While the estimated probabilities are specific to this profile, the proportional changes in probabilities after vaccination do not vary across characteristics and can therefore be generalised to other profiles. Dashed lines indicate the timing of vaccination. Shaded areas are $95 \%$ confidence intervals. 
medRxiv preprint doi: https://doi.org/10.1101/2021.12.09.21267516; this version posted December $9,2021$. The copyright holder for this preprint (which was not certified by peer review) is the author/funder, who has granted medRxiv a license to display the preprint in perpetuity.

It is made available under a CC-BY 4.0 International license.

Supplementary Figure $\mathbf{2 h}$. Modelled probabilities of Long Covid for a hypothetical study participant, sensitivity analysis 8: infection date for participants whose time of infection was determined by symptom onset $>14$ days before a positive swab reset to date of first positive swab

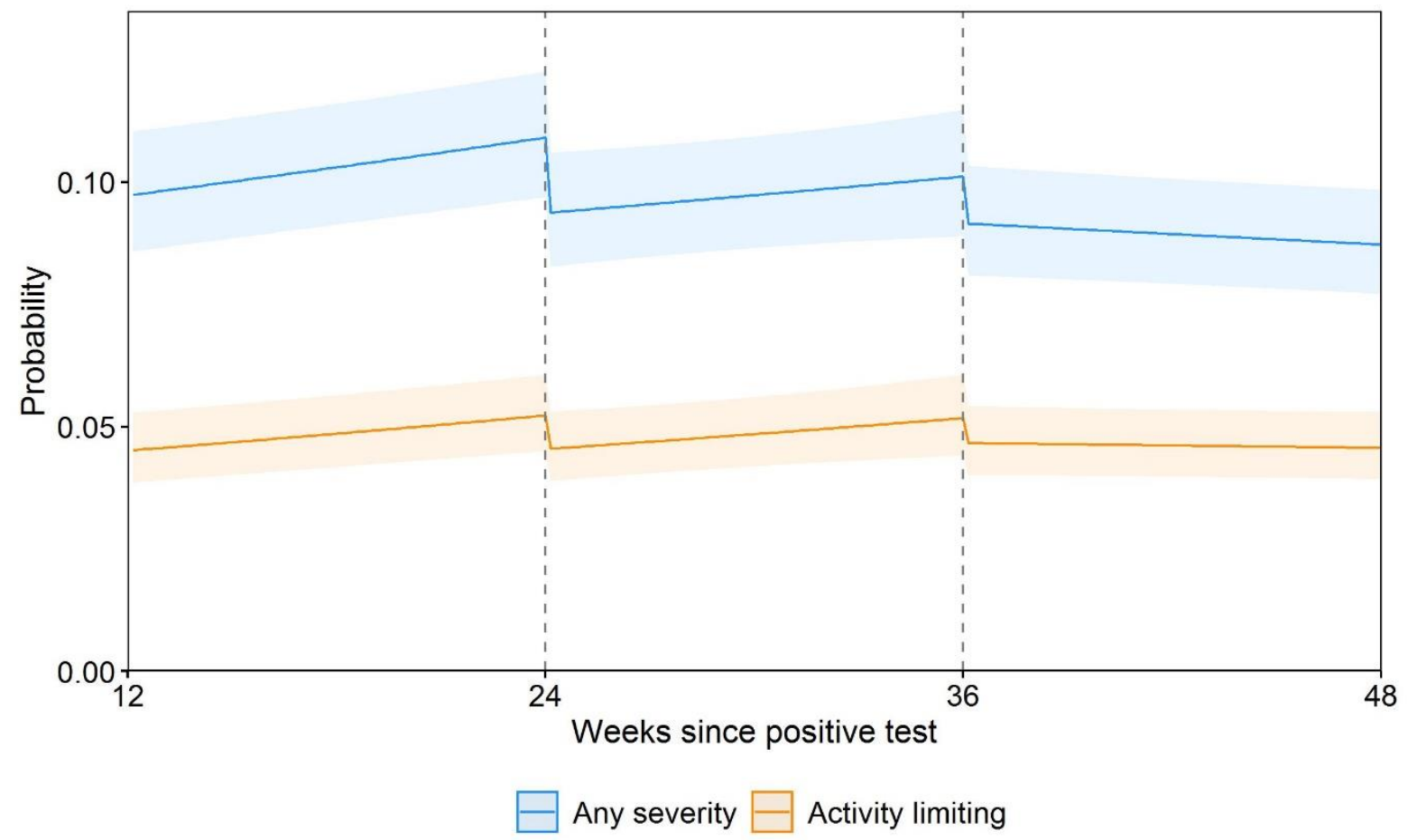

Notes: The infection date was moved forward by a median of 249 days among 698 participants $(2.5 \%)$ whose time of infection was determined by symptom onset (rather than a confirmatory test) and was $>14$ days before a positive swab. Probabilities are shown for a participant aged 50 years and in the modal group for other covariates (female, white, living in London, in an area in the least deprived quintile group, not a patient-facing health or social care worker, no pre-existing health conditions, not hospitalised at the acute phase of infection, and infected on 7 September 2020). While the estimated probabilities are specific to this profile, the proportional changes in probabilities after vaccination do not vary across characteristics and can therefore be generalised to other profiles. Dashed lines indicate the timing of vaccination. Shaded areas are $95 \%$ confidence intervals. 
medRxiv preprint doi: https://doi.org/10.1101/2021.12.09.21267516; this version posted December 9, 2021. The copyright holder for this preprint (which was not certified by peer review) is the author/funder, who has granted medRxiv a license to display the preprint in perpetuity.

It is made available under a CC-BY 4.0 International license.

Supplementary Figure 3a. Modelled probabilities of Long Covid of any severity for hypothetical study participants who received their first vaccination $6,9,12$, and 15 months after infection

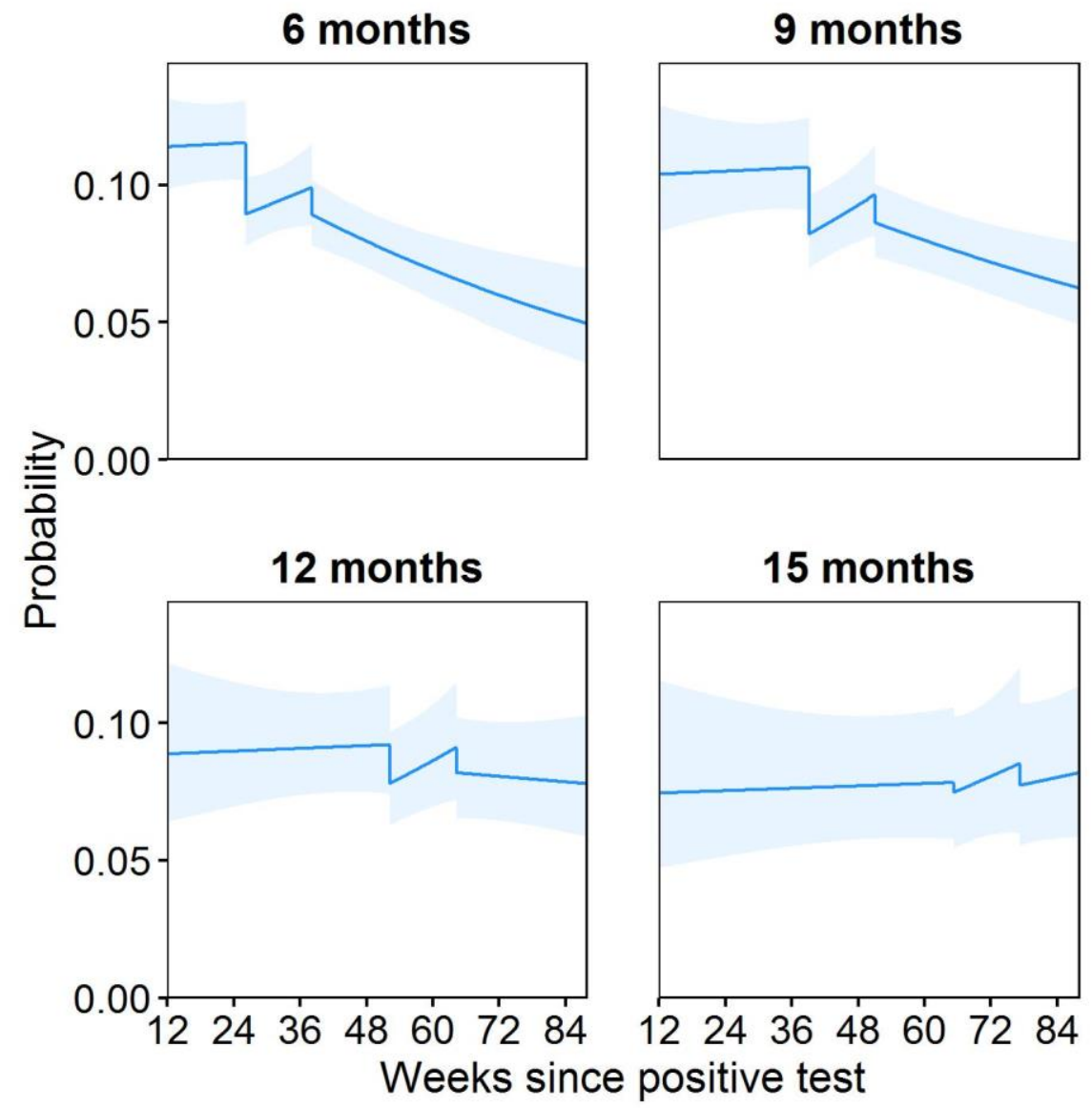

Notes: Probabilities are shown for a participant of approximately mean age (50 years) and in the modal group for other covariates (female, white, living in London, in an area in the least deprived quintile group, not a patient-facing health or social care worker, no pre-existing health conditions, not hospitalised at the acute phase of infection, and infected on 7 September 2020). While the estimated probabilities are specific to this profile, the proportional changes in probabilities after vaccination do not vary across characteristics and can therefore be generalised to other profiles. Dashed lines indicate the timing of vaccination. Shaded areas are $95 \%$ confidence intervals. Probabilities were obtained by interacting all four exposure variables (changes in level and slope after each dose) with duration from infection to first vaccination (modelled as a restricted cubic spline). 
medRxiv preprint doi: https://doi.org/10.1101/2021.12.09.21267516; this version posted December 9, 2021. The copyright holder for this preprint (which was not certified by peer review) is the author/funder, who has granted medRxiv a license to display the preprint in perpetuity.

It is made available under a CC-BY 4.0 International license.

Supplementary Figure 3b. Modelled probabilities of activity-limiting Long Covid for hypothetical study participants who received their first vaccination $6,9,12$, and 15 months after infection

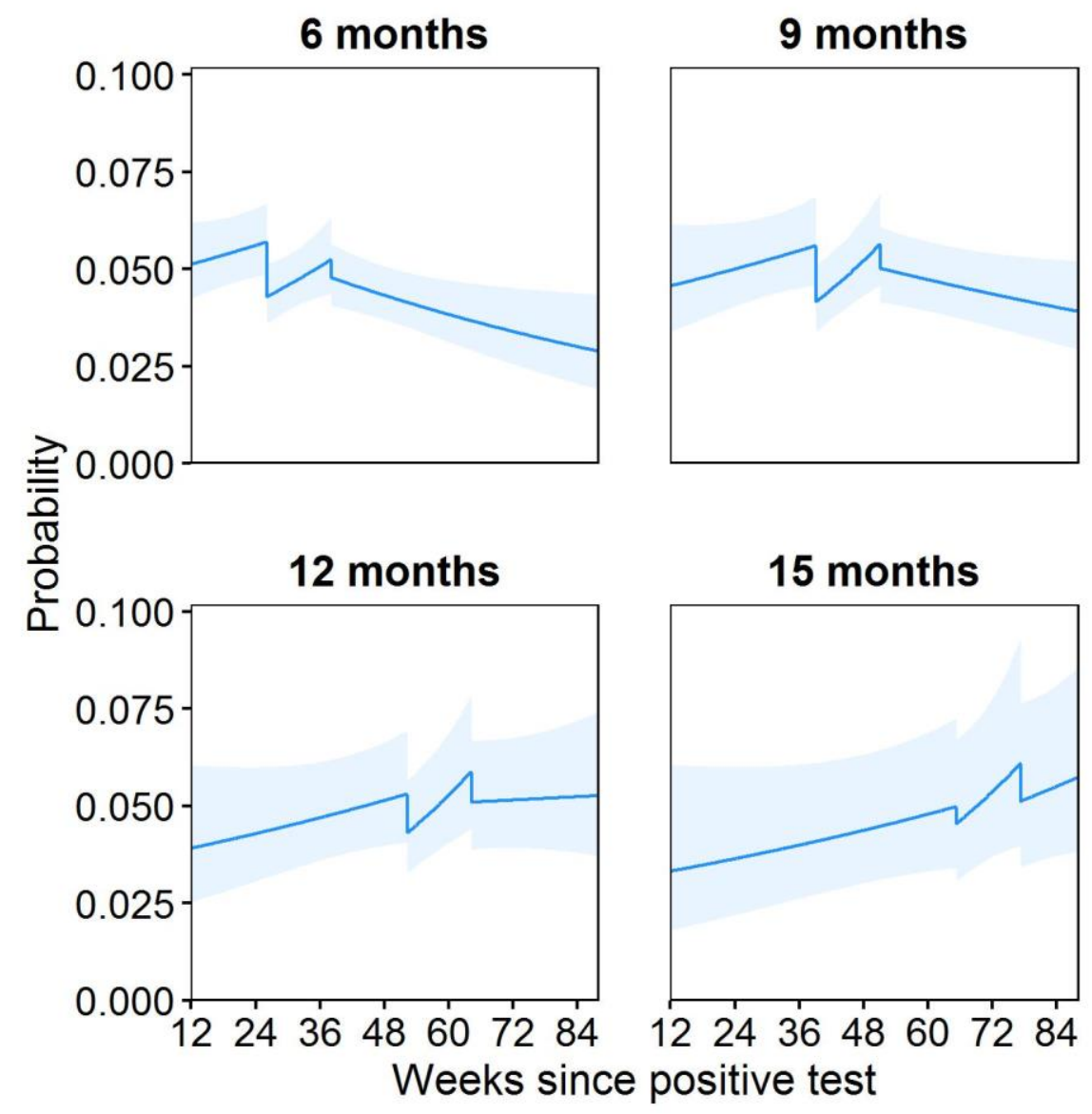

Notes: Probabilities are shown for a participant of approximately mean age (50 years) and in the modal group for other covariates (female, white, living in London, in an area in the least deprived quintile group, not a patient-facing health or social care worker, no pre-existing health conditions, not hospitalised at the acute phase of infection, and infected on 7 September 2020). While the estimated probabilities are specific to this profile, the proportional changes in probabilities after vaccination do not vary across characteristics and can therefore be generalised to other profiles. Dashed lines indicate the timing of vaccination. Shaded areas are $95 \%$ confidence intervals. Probabilities were obtained by interacting all four exposure variables (changes in level and slope after each dose) with duration from infection to first vaccination (modelled as a restricted cubic spline). 